\title{
(E)-Ethyl-2-cyano-2-(((2,4,6-trichlorobenzoyl)oxy)imino)acetate: A Modified Yamaguchi Reagent for Enantioselective Esterification, Thioesterification, Amidation, and Peptide Synthesis
}

\author{
Jyoti Chandra, Srinivasa Rao Manne, Sandip Mondal, and Bhubaneswar Mandal*i) \\ Department of Chemistry, Indian Institute of Technology Guwahati, Guwahati, Assam 781039, India
}

Supporting Information

ABSTRACT: Here, the synthesis and applications of (E)-ethyl-2cyano-2-(((2,4,6-trichlorobenzoyl)oxy)imino)acetate as a racemization suppressing and easily recyclable version of the Yamaguchi reagent that can be used for amide and peptide synthesis are reported. We demonstrated its application in racemization-free esterification, thioesterification, amidation, and peptide bond formation. We successfully synthesized oligopeptides on the solid support in dimethylformamide as well as in solution (dichloromethane) by applying this coupling reagent. It is important to note that a mixed-anhydride-based method provides peptide-forming reactions as good as the current methods using built-in coupling reagents. Mechanism investigation, racemization suppression, and recyclability are also discussed.

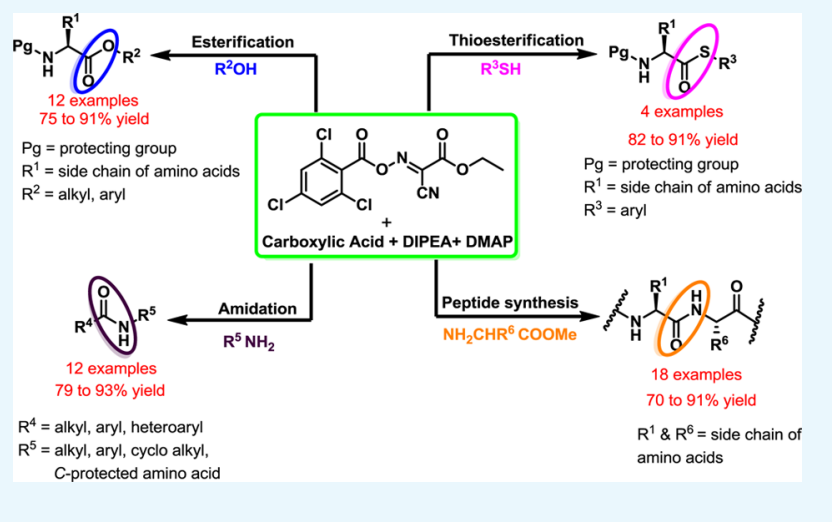

desired products decreases and purification of the products becomes cumbersome. Most importantly, these reagents become useless for the stepwise synthesis of oligopeptides because of the accumulation of undesired epimerized analogues at each step. Usually, $N$-hydroxy amine reagents, for example, hydroxybenzotriazole (HOBt) and hydroxyazabenzotriazole (HOAt), are frequently used as additive with the coupling reagents ${ }^{14}$ to prevent the racemization during peptide synthesis. However, due to the explosive nature of HOBt and HOAt, recently, ethyl-2hydroxyimino-2-cyanoacetate (oxyma) has been suggested as a racemization suppressant in diisopropylcarbodiimide ${ }^{15}$ and oxyma-based phosphate ${ }^{16}$-mediated peptide syntheses. Earlier, we also reported the utility of oxyma-based reagents for racemization-free peptide synthesis and various other organic transformations. ${ }^{17}$

We describe herein a differently modified Yamaguchi reagent, (E)-ethyl-2-cyano-2-(((2,4,6-trichlorobenzoyl)oxy)imino)acetate (Scheme 1, TCBOXY, I), which can be efficiently used for esterification, amidation, and peptide synthesis without causing detectable racemization. To the best of our knowledge, to date, there is no report on the racemization-free amide and peptide synthesis using Yamaguchi and modified Yamaguchi reagents.

Received: April 16, 2018

Accepted: May 25, 2018

Published: June 6, 2018 
Scheme 1. Preparation of the Coupling Reagent, Ethyl-2-cyano-2-(((2,4,6-trichlorobenzoyl)oxy)imino)acetate (TCBOXY, I)<smiles>CCOC(=O)/C(C#N)=N/O</smiles>

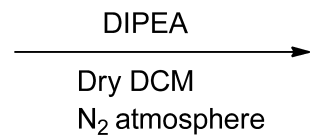

$2 \mathrm{~h}, 0^{\circ} \mathrm{C}$<smiles>CCOC(=O)/C(C#N)=N/OC(=O)c1c(Cl)cc(Cl)cc1Cl</smiles>

TCBOXY (I)

\section{RESULTS AND DISCUSSION}

Reagent I can readily be synthesized by reacting oxyma with $\mathrm{TCBCl}$ in the presence of Hunig's base ( $\mathrm{N}, \mathrm{N}$-diisopropylethylamine (DIPEA)) under nitrogen atmosphere and dry dichloromethane (DCM) at $0{ }^{\circ} \mathrm{C}$ for $2 \mathrm{~h}$ (Scheme 1$)$. Simple aqueous workup and recrystallization from hexane results in $\mathbf{I}$ that can be directly used for coupling reactions. Reagent I does not degrade at room temperature $\left(25^{\circ} \mathrm{C}\right)$ and therefore it can be stored for an extended period. A time-dependent high-performance liquid chromatography (HPLC) study indicated no change of I until 2 months (Figures S4 and S5, Supporting Information).

Its coupling efficiency was first investigated by the reaction between benzoic acid and cyclohexylamine in the presence of DIPEA (Table 1). We observed only $30 \%$ of the desired product

Table 1. Optimization of Reaction Conditions ${ }^{a}$

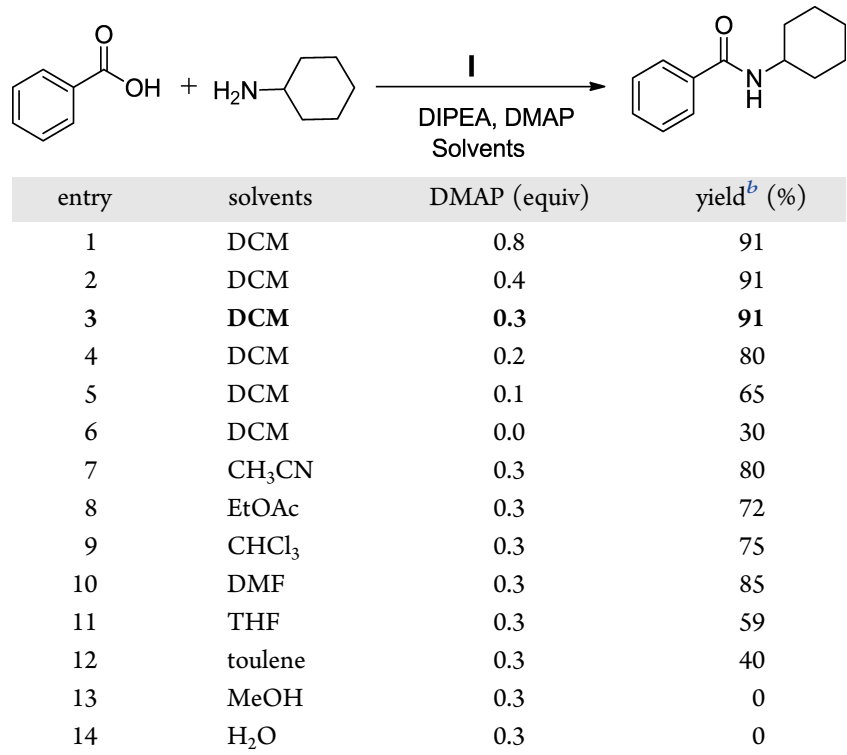

${ }^{a}$ Reaction conditions: benzoic acid (122 mg, $\left.1 \mathrm{mmol}\right)$, TCBOXY (349 mg, $1 \mathrm{mmol}$ ), DIPEA (193 mg, $1.5 \mathrm{mmol}$ ), DMAP, cyclohexylamine $\left(99 \mathrm{mg}, 1 \mathrm{mmol}\right.$ ) stirred at room temperature for $15 \mathrm{~min} .{ }^{b}$ Isolated yield.

and $60 \%$ of the corresponding amide of 2,4,6-trichlorobenzoic acid (Figures S154-S156, Supporting Information). To avoid the formation of side products, we used a catalytic amount of DMAP, which acted as a selective acyl-transfer reagent. ${ }^{18} \mathrm{We}$ screened the various amounts of DMAP using the same reaction in DCM (Table 1). We observed a 91\% yield of the desired product with 0.3 equiv of DMAP. By increasing the amount of DMAP beyond 0.3 equiv, no notable improvement in the yield was observed (entries 1 and 2). But, when we decreased the same below 0.3 equiv, the yield dropped (entries 4 and 5). Next, we screened several solvents using reagent $\mathbf{I}$ (1 equiv) with the catalytic amount of DMAP (0.3 equiv). We found that DCM, $\mathrm{CH}_{3} \mathrm{CN}$, EtOAc, $\mathrm{CHCl}_{3}$, and dimethylformamide (DMF) afforded very good yields (entries 3 and 7-10). However, there was no reaction in $\mathrm{CH}_{3} \mathrm{OH}$ and $\mathrm{H}_{2} \mathrm{O}$ (entries 13 and 14). Therefore, 0.3 equiv of DMAP and DCM as a solvent were accepted under optimized conditions (entry 3 ).

Under the optimized conditions, we proceeded to investigate the scope of esterification using various carboxylic acids and alcohols by using I. Reactions worked well with the sterically hindered amino acids (Scheme 2, 2a-d) as well as with heterocyclic, aromatic, and aliphatic carboxylic acids $(\mathbf{2 e}-\mathbf{j})$. The reaction also worked with secondary alcohol $(\mathbf{2 h})$ in very good yield. We also extended this protocol for thioesterification ( $2 \mathrm{k}-$ n). A broad range of carboxylic acids was tolerated, including those bearing electron-donating groups ( 21 and $2 n$ ) and an electron-withdrawing group $(\mathbf{2 m})$, with aromatic thiols bearing neutral, electron-donating, and electron-withdrawing substituents.

Further, we extended this protocol for amidation reactions. Interestingly, the reactions worked well with the aromatic carboxylic acids (Scheme 2, 20-x), aliphatic carboxylic acids $(2 \mathbf{y}-\mathbf{z})$, aromatic amines $(\mathbf{2 o})$, aliphatic amines $(\mathbf{2} \mathbf{p}-\mathbf{w}$ and $\mathbf{2 z})$, and C-protected amino acids ( $2 \mathbf{x}$ and $2 \mathbf{y})$.

We further explored the applicability of $\mathbf{I}$ for peptide synthesis in solution with various $\mathrm{N}$-protected amino acids bearing various side chains (Scheme 3). The reactions worked well with the common $\mathrm{N}$-protections, such as Bz (Scheme 3, 3a), Fmoc (3b to rac-3n), Boc (3o and $3 \mathbf{p}), \mathrm{Cbz}(3 \mathbf{q}-\mathbf{s})$, and sterically hindered amino acids with good to excellent yields.

We further synthesized a tetrapeptide, Boc-Val-Val-Ile-Ala$\mathrm{OMe}$, the C-terminal segment of the amyloid $\beta$-peptide ${ }^{20}$ (Figure 1a), in DCM solution following Boc-chemistry. The yield of the crude peptide (after precipitation with cold ether but before purification by HPLC) was 75\%, while the purity was $99 \%$, as determined by reversed-phase (RP)-HPLC analysis (Figures S195 and S196, Supporting Information), indicating cleanliness of the procedure. Later, we synthesized acyl carrier protein (ACP) (24-33) peptide segment (ACP, acyl carrier protein: Asp-Asn-Ala-Ser-Phe-Val-Glu-Asp-Leu-Gly- $\mathrm{NH}_{2}$, Figure 1b) and the tropoelastin peptide segment ((Pro-Gly-Val-Gly-Val)$_{2}-\mathrm{NH}_{2}$, Figure $\left.1 \mathrm{c}\right)^{21}$ by stepwise coupling of amino acids on the Rink Amide MBHA resin following Fmoc/t-Bu orthogonal protection strategy. The electrospray ionization (ESI)-mass spectrometry (MS) data and HPLC profiles of each segment during the synthesis of ACP (24-33) (Table S1 and Figures S201-S218, Supporting Information) indicate occurrences of neither incomplete coupling nor side reactions during the coupling steps. Considering the scale of the reaction sequences, yields (21\% for ACP (24-33) and 30\% for the elastin peptide) with respect to the resin loading were good (Figures S217, S218 and S199, S200). We further synthesized specific segments of gramicidin A, B, and $\mathbf{C}$ on Wang resin (Figure 1d). The general structure of the segments of gramicidin A, B, and C is Xaa-D-LeuL-Trp-D-Leu-L-Trp-OH, where the side chain of Xaa varied (Figure 1d). We obtained these peptides also in good yield, i.e., 23,28 , and $26 \%$ of gramicidin A, B, and C segments, respectively, 
Scheme 2. Esterification, Thioesterification, and Amidation by Using $\mathrm{I}^{a}$

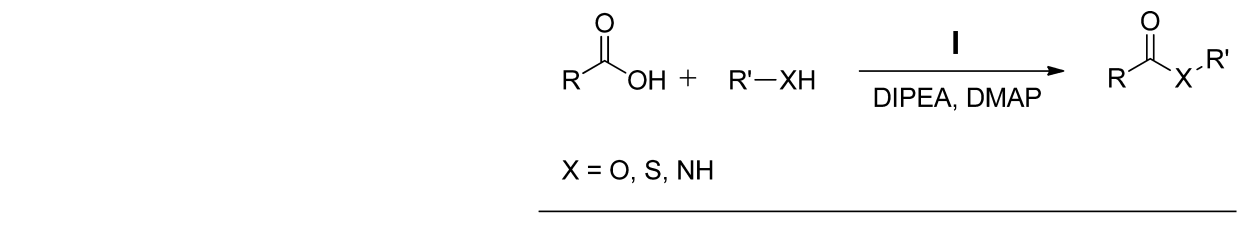

Fmoc

2a, $81 \%$<smiles>CCC(C)[C@H](NC(=O)OC(C)(C)C)C(=O)Oc1ccc([N+](=O)[O-])cc1</smiles>

2d, $85 \%$<smiles>CC(C)[C@H]1CCCCC1OC(=O)c1ccccn1</smiles>

$2 \mathrm{~h}, 75 \%$<smiles>Cc1ccc(SC(=O)c2ccc(C)cc2)cc1</smiles>

21 $93 \%$<smiles>COc1ccc(C(=O)NC2CC2)cc1</smiles>

$2 p, 82 \%$<smiles>O=C(NC1CCCCC1)c1ccccc1</smiles>

$2 \mathrm{t}, 93 \%$<smiles>O=C(NN[C@@H](Cc1ccccc1)C(=O)OCc1ccccc1)OC(F)F</smiles>

rac-2a, $80 \%$<smiles>C#CCOC(=O)c1ccc2ccccc2n1</smiles>

2e, $89 \%$<smiles>O=C(Oc1cccc(Br)c1)c1ccc2ccccc2n1</smiles>

$2 \mathrm{i}, 83 \%$<smiles>Cc1ccc(SC(=O)c2ccccc2[N+](=O)[O-])cc1</smiles>

$2 \mathrm{~m}, 86 \%$<smiles>C#CCNC(=O)c1ccc(C)cc1</smiles>

$2 q, 85 \%$<smiles>O=C(NCc1ccccc1)c1ccc2ccccc2c1</smiles>

$2 u, 89 \%$<smiles>CC(C)C(NC(F)F)C(=O)OCc1ccccc1</smiles>

2b, $82 \%$<smiles>C/C=C/COC(=O)c1ccc2ccccc2c1</smiles>

2f, $91 \%$<smiles>C#CCOC(=O)/C=C/c1ccc(OC)cc1</smiles>

2j, $91 \%$<smiles>CC(C)[C@H](NC(=O)OC(F)(F)F)C(=O)Sc1ccccc1</smiles><smiles>Cc1ccc(C(=O)Sc2ccc([N+](=O)[O-])cc2)cc1</smiles>

2 n, $82 \%$<smiles>CCCCNC(=O)c1ccc2ccccc2n1</smiles>

$2 \mathrm{r}, 87 \%$<smiles>CC(C)(C)NC(=O)c1ccccn1</smiles>

2v, $86 \%$<smiles>CC(C)(NC(F)F)C(=O)OCc1ccccc1</smiles>

2c, $78 \%$<smiles>O=C(Cc1ccccc1)OCc1ccco1</smiles>

2g, $87 \%$
$2 \mathrm{k}, 91 \%$<smiles>O=C(Nc1ccccc1)c1ccccc1[N+](=O)[O-]</smiles>

2o, $79 \%$<smiles>O=C(NCc1ccccc1)c1ccccc1</smiles>

2s, $91 \%$<smiles>CC(C)(C)NC(=O)c1ccc2ccccc2c1</smiles>

2w, $80 \%$

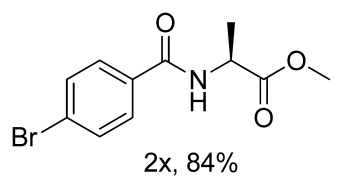<smiles>COC(=O)[C@H](Cc1ccccc1)NC(=O)C(C)(C)C</smiles><smiles>O=C(Cc1ccccc1)NC1CCCCC1</smiles>

2y, $81 \%$

${ }^{a}$ Reaction conditions: acid ( $\left.1 \mathrm{mmol}\right)$, I ( $\left.1 \mathrm{mmol}\right)$, DIPEA ( $\left.1.5 \mathrm{mmol}\right)$, DMAP (0.3 mmol), and alcohol, thiol, or amine (1.2 mmol), stirred at room temperature for 5-30 min. Isolated yields after column chromatographic purification are mentioned.

with respect to the resin loading after purification using RPHPLC (Figures S219-S224, Supporting Information).

Epimerization during such syntheses is highly important for industry and academia, but we could not find any systematic study on the epimerization potential of such reagents. Therefore, we investigated the epimerization potential of the Yamaguchi and related reagents and compared it to that of $I$. We first synthesized DL-Fmoc-Phe-OBn (rac-2a) using the optimized protocol and 
Scheme 3. Wide Scope of the Synthesis of Peptides in Solution Using $\mathrm{I}^{a}$

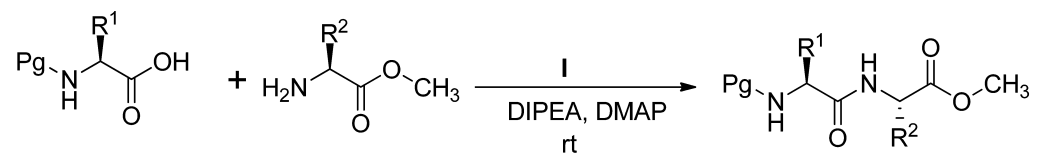

$\mathrm{Pg}=$ protecting group<smiles>COC(=O)[C@H](NC(=O)C(C)(C)NC(=O)c1ccccc1)C(C)C</smiles>

3a, $80 \%$<smiles>COC(=O)C(NC(=O)[C@H](Cc1ccccc1)NC(F)(F)F)c1ccccc1</smiles>

$3 e, 86 \%$<smiles>COC(=O)[C@H](Cc1ccccc1)NC(=O)CNC(F)F</smiles>

$3 i, 88 \%$<smiles>COC(=O)[C@H](C)NC(=O)C(C)NC(F)F</smiles>

3m, $91 \%$<smiles>COC(=O)[C@H](C)NC(=O)C(Cc1ccccc1)NC(F)F</smiles>

3b, $89 \%$<smiles>COC(=O)[C@H](NC(=O)C(NC(F)F)C(C)C)c1ccccc1</smiles>

$3 f, 87 \%$<smiles>COC(=O)CNC(=O)C(C)(C)NC(F)F</smiles>

$3 \mathrm{j}, 85 \%$<smiles>COC(=O)CNC(=O)C(Cc1ccccc1)NC(F)(F)F</smiles><smiles>COC(=O)[C@H](NC(=O)[C@H](CC(C)C)NC(=O)F)C(C)C</smiles>

3c, $85 \%$<smiles>COC(=O)[C@H](CC(C)C)NC(=O)C(C)NCC(C)C</smiles><smiles>COC(=O)[C@H](CO)NC(=O)C(Cc1ccccc1)NCC(F)F</smiles>

3k, $91 \%$<smiles>COC(=O)CNC(=O)[C@H](Cc1ccccc1)NC(F)F</smiles>
rac-3n, $87 \%$<smiles>COC(=O)[C@H](C)NC(=O)C(C)(C)NC(F)F</smiles>

$3 d, 89 \%$<smiles>COC(=O)[C@H](CC(C)C)NC(=O)[C@H](C)NC(=O)[18OH]</smiles><smiles>COC(=O)[C@H](Cc1ccccc1)NC(=O)C(Cc1ccccc1)NC(F)F</smiles>

$31,89 \%$<smiles>COC(=O)C(NC(=O)[C@H](Cc1ccccc1)NC(=O)OC(C)(C)C)c1ccccc1</smiles>

3o, $70 \%$<smiles>COC(=O)C(CC(C)C)NC(=O)[C@H](Cc1ccccc1)NC(=O)OC(C)(C)C</smiles>

$3 p, 74 \%$

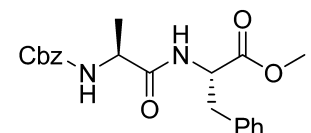

$3 q, 86 \%$<smiles>COC(=O)[C@H](NC(=O)[C@H](Cc1ccccc1)NC(=O)[O-])C(C)C</smiles>

$3 r, 83 \%$<smiles>COC(=O)[C@H](NC(=O)C(Cc1ccccc1)NC(=O)CNC(=O)OCc1ccccc1)C(C)C</smiles>

3s, $90 \%$

${ }^{a}$ Reaction conditions: acid $(1 \mathrm{mmol})$, I $(1 \mathrm{mmol})$, DIPEA $(1.5 \mathrm{mmol})$, DMAP $(0.3 \mathrm{mmol})$, and amine $(1.5 \mathrm{mmol})$, stirred at room temperature for 20-120 min. Isolated yields after column chromatographic purification are mentioned.

passed through a chiral column. Two well-separated peaks, corresponding to the two enantiomers, were observed in HPLC profile (Figures 2 and S157-S159, Supporting Information) that were used as a reference. Next, we synthesized L-Fmoc-Phe-OBn (2a) using the Yamaguchi reagent in the absence of DMAP and in the presence of DMAP, the modified Yamaguchi reagent (TCB-DMAP), and I. The products were passed through the chiral column using the same eluant. Although all of the tested reagent combinations resulted in $12-24 \%$ epimerization, I did not cause any detectable epimerization (Figures 2 and S160S166, Supporting Information). This result indicates that no racemization occurred during the coupling reaction using I, unlike other similar reagents. The above results also suggest that DMAP has no apparent role in racemization suppression.

We synthesized Fmoc-L-Ala-L-Leu-OMe (3g) and Fmoc-DLAla-L-Leu-OMe (3h) using I to investigate the associated racemization in peptide synthesis. The appearance of the single peak in the HPLC profile of $\mathbf{3 g}$ corresponds to the unique stereoisomeric product, whereas the presence of the twin peak in the same of $3 \mathbf{h}$ indicates the presence of two diastereomeric products (Figures 3 and S167-S171, Supporting Information). The ${ }^{1} \mathrm{H}$ and ${ }^{13} \mathrm{C}$ NMR spectra of $3 \mathbf{h}$ and $\mathbf{3 g}$ were also compared (Figures 3 and S106-S111, Supporting Information). We found one singlet at $\delta=3.72 \mathrm{ppm}$ for the methoxy proton of $3 \mathrm{~g}$ and two singlets at $\delta=3.70$ and $3.68 \mathrm{ppm}$ for the methoxy proton of $3 \mathrm{~h}$ in the ${ }^{1} \mathrm{H}$ NMR spectra. Similarly, in the ${ }^{13} \mathrm{C}$ NMR spectra, we found two peaks at $\delta=173.4$ and $172.3 \mathrm{ppm}$ corresponding to the two carbonyls of the amide and the ester groups of $3 \mathbf{g}$, indicating the presence of the single diastereomer, whereas the presence of four peaks at $\delta=173.4,173.3,172.5$, and $172.4 \mathrm{ppm}$ for those carbonyl carbons of $3 \mathrm{~h}$ indicates the presence of two diastereomeric products (Figure 3). Therefore, it was inferred that no detectable racemization occurred during the synthesis of the mentioned dipeptides using I. Similarly, comparison of the HPLC profiles (Figures S172-S176, Supporting Information) of the $\mathrm{L}$ and DL forms of the Fmoc-Phe-Gly-OMe dipeptides (3n 
(a)<smiles>CCC(C)[C@H](NC(=O)[C@H](NC(=O)[C@@H](NC(=O)OCc1ccccc1)C(C)C)C(C)C)C(=O)N[C@@H](C)C(=O)OC</smiles>

(b)<smiles>CC(C)C[C@H](NC(=O)[C@H](CC(=O)O)NC(=O)[C@H](CCC(=O)O)NC(=O)[C@H](NC(=O)[C@H](Cc1ccccc1)NC(=O)[C@H](CO)NC(=O)[C@H](C)NC(=O)[C@H](CC(N)=O)NC(=O)[C@H](N)CC(=O)O)C(C)C)C(=O)NCC(N)=O</smiles>

(c)

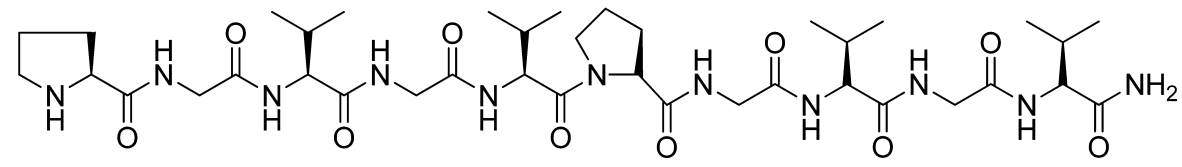

(d)<smiles>[R]C(N)C(=O)N[C@@H](CC(C)C)C(=O)N[C@@H](Cc1c[nH]c2ccccc12)C(=O)N[C@@H](CC(C)C)C(=O)N[C@@H](Cc1c[nH]c2ccccc12)C(=O)NCC(=O)O</smiles><smiles>[R]=CCc1c[nH]c2ccccc12</smiles>

gramicidin A gramicidin B

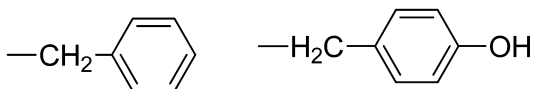

gramicidin C

Figure 1. Sequences of the synthesized long peptides: (a) Boc-VVIA-OMe, in solution; (b) DNASFVEDLG-NH ${ }_{2}$ (c) PGVGVPGVGV-NH PG $_{2}$ and (d) segments of gramicidin A, B, and C using solid phase peptide synthesis strategy.

and rac-3n, respectively) leads to the same conclusion. Also, for all of the remaining L,L-dipeptides depicted in Scheme 3, single peaks corresponding to the only stereoisomeric products were noted, confirming the occurrence of no detectable racemization during peptide synthesis by $\mathbf{I}$.

Next, we synthesized a tripeptide Z-Gly-Phe-Val-OMe (Scheme 3, 3s and Figures S145-S147, S177 and S178, Supporting Information) in solution using I, determined the yield and the degree of racemization, and compared the results to those reported for popular coupling reagents, such as $\mathrm{N}$ [(dimethylamino)-1H-1,2,3-triazolo[4,5-b] pyridin-1-yl-methylene]-N-ethylmethanaminium hexafluorophosphate $N$-oxide (HATU), 1-((dimethylamino)-(morpholino)methylene)-1H$[1,2,3]$ triazolo[4,5-b]pyridinium hexafluorophosphate-3-oxide (HDMA), 1-((dimethylamino)(morpholino)methylene)-1Hbenzotriazolium hexafluorophosphate-3-oxide (HDMB), and $\mathrm{N}$-[(1H-benzotriazol-1-yl)-(dimethylamino)methylene $] \mathrm{N}$ methylmethanaminium hexafluorophosphate $\mathrm{N}$-oxide (HBTU). ${ }^{19}$ Although the yields were comparable, no race- mization could be observed during the synthesis by using I unlike the other reagents (Table 2).

Next, we turned our attention to the mechanism elucidation. As suggested in the original article, Yamaguchi reagent, which is a sterically hindered benzoyl chloride, works via the formation of the mixed-anhydride intermediate ${ }^{10}$ (II, Scheme 4), followed by the nucleophilic attack of DMAP to the less hindered electrophilic center of II to generate the resonance-stabilized $N$-acyl pyridinium salt intermediate III. ${ }^{13}$ Such preference of DMAP results in the regioselectivity of the reaction. Further attack of the added nucleophile, e.g., alcohol or amine, leads to the final product. However, SantaLucia and Dhimitruka ${ }^{12}$ suggested that aliphatic carboxylates should be more reactive toward the aliphatic moiety of the mixed anhydride II due to the steric factor. Thus, once II is formed, the less hindered carboxylate reacts with it to generate the relatively less hindered symmetrical anhydride intermediate (IV). They indeed demonstrated that the byproduct, 2,4,6-trichlorobenzoate anion, did not 


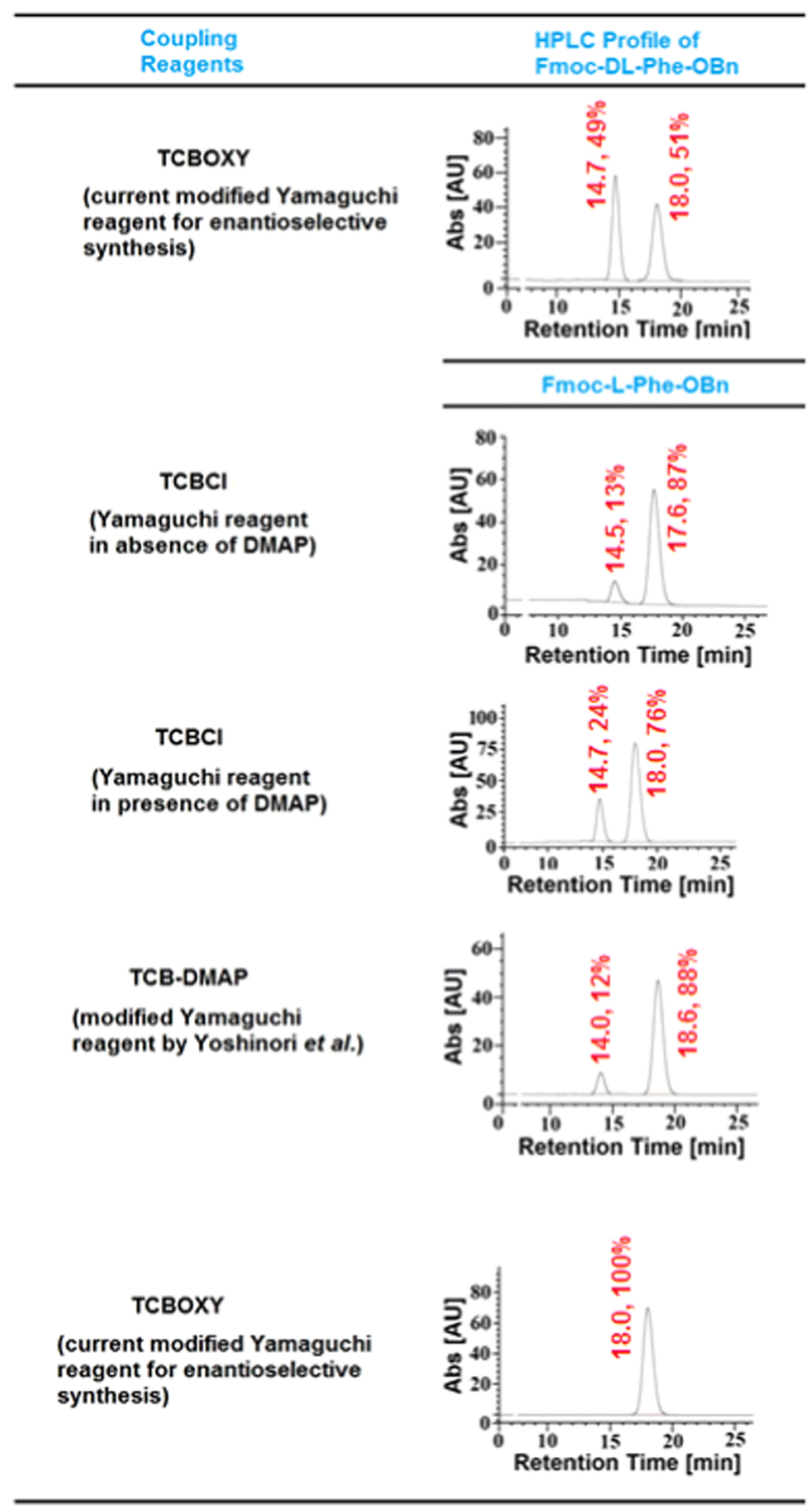

Figure 2. HPLC images to compare the epimerization caused by various coupling reagents.

react with the Yamaguchi reagent to form 2,4,6-trichlorobenzoic anhydride, instead intermediate IV was generated exclusively.

Therefore, most probably in the TCBOXY-mediated reaction, the nucleophile generated by the deprotonation of the substrate carboxylic acid in the presence of DIPEA attacks the carbonyl carbon of I, forming the mixed anhydride II, and releases the resonance-stabilized oxyma anion. Then, another molecule of the already created carboxylate attacks the less hindered carbonyl of II to generate IV. DMAP attacks regioselectively at the less hindered carbon atom of either II or IV, forming the $N$-acyl pyridinium salt III. The released oxyma anion then attacks the carbonyl carbon of III, resulting in the formation of the intermediate $\mathbf{V}$, which is the oxyma ester of the substrate carboxylic acid. $\mathbf{V}$ then undergoes nucleophilic substitution in a stereoselective fashion to produce the corresponding esters, thioesters, amides, and peptides. The intermediate $\mathbf{V}$ was isolated as a product in a similar reaction of a carboxylic acid (Fmoc-Ala$\mathrm{OH})$, I, the appropriate amount of DMAP and DIPEA, but devoid of the nucleophile. It was characterized by ${ }^{1} \mathrm{H}$ NMR and ${ }^{13} \mathrm{C}$ NMR spectroscopies (Figures S6 and S7, Supporting Information).

Chemical waste generation and nonrecyclability are common problems for the majority of the popular peptide-coupling reagents. Therefore, a recent trend is to develop easily recyclable coupling reagents that are highly required for sustainability. ${ }^{22} \mathrm{We}$ investigated the recyclability of $\mathbf{I}$. We repeated the synthesis of $2 \mathbf{v}$ (Scheme 2) for that. After completion of the reaction, the product and byproducts, oxyma (a) and trichlorobenzoic acid (b) (Scheme 5 and Figures S148-S153, Supporting Information), were purified by eluting with specific eluents from a silica gel column. The recovered $\mathbf{b}$ was chlorinated with thionyl chloride by heating at $110-114{ }^{\circ} \mathrm{C}$ in toluene for $3 \mathrm{~h}$ and mixed with the recovered $\mathbf{a}$ in the presence of DIPEA to obtain I with $52 \%$ overall yield with respect to the initial I used. Alternatively, the recovered $\mathbf{a}$ and $\mathbf{b}$ were recombined by merely heating in the presence of silica gel under microwave irradiation ${ }^{23}$ (Scheme 5)based dehydration without using unhealthy thionyl chloride. By this way, we were able to recover byproducts and recombine to regenerate the coupling reagent easily.

\section{CONCLUSIONS}

Yamaguchi reagent could solve a lot of practical problems, but to the best of our knowledge, could never be used as a peptidecoupling reagent, primarily because of the arduous acid chloride and significant racemization during condensation. We have developed a modified Yamaguchi reagent, TCBOXY (I), which can be efficiently used for the syntheses of esters, thioesters, amides, peptides in both solution and solid support with very good to excellent yield. The advantages of TCBOXY are as follows: (a) its preparation protocol is easy and involves singlestep reaction; (b) it suppresses racemization during the coupling reaction and allows enantioselective syntheses; (c) only 2,4,6trichlorobenzoic acid and oxyma are generated as byproducts, which are nontoxic and can be recovered and recycled to generate the same coupling reagent easily that can be used in the same pool; (d) operationally simple, as both of the byproducts are acidic in nature and just basic workup renders pure products. Thus, the described method for the synthesis of the mentioned compounds using this new reagent is a more eco-friendly and green process than the current alternatives discussed in Introduction.

\section{EXPERIMENTAL SECTION}

General Information. All of the reagents, except those mentioned, were procured from usual commercial sources. NMR experiments were performed on 600 and $400 \mathrm{MHz}$ spectrometers using $\mathrm{CDCl}_{3}$. Tetramethylsilane was used as an internal standard. Chemical shifts $(\delta)$ were indicated in parts per million. Spin-spin coupling constants $(J)$ were indicated in hertz. The multiplicity of the signals was indicated as follows: s (singlet), $d$ (doublet), $\mathrm{t}$ (triplet), q (quartet), and $\mathrm{m}$ (multiplet). Thin-layer chromatography using silica gel G254 was used to monitor the reactions. Column chromatography using silica gel (60-120 mesh) and EtOAc/hexane as eluent was used to purify the products. Melting points and Fourier transform infrared (FT-IR) spectra were recorded on a dedicated meting point apparatus and an FT-IR spectrometer, respectively. High-resolution mass spectrometry (HRMS) experiments were performed on a Micromass quad time-of-flight (Q-TOF) ESI-MS instrument and a Q-TOF liquid chromatography/MS system. HPLC 


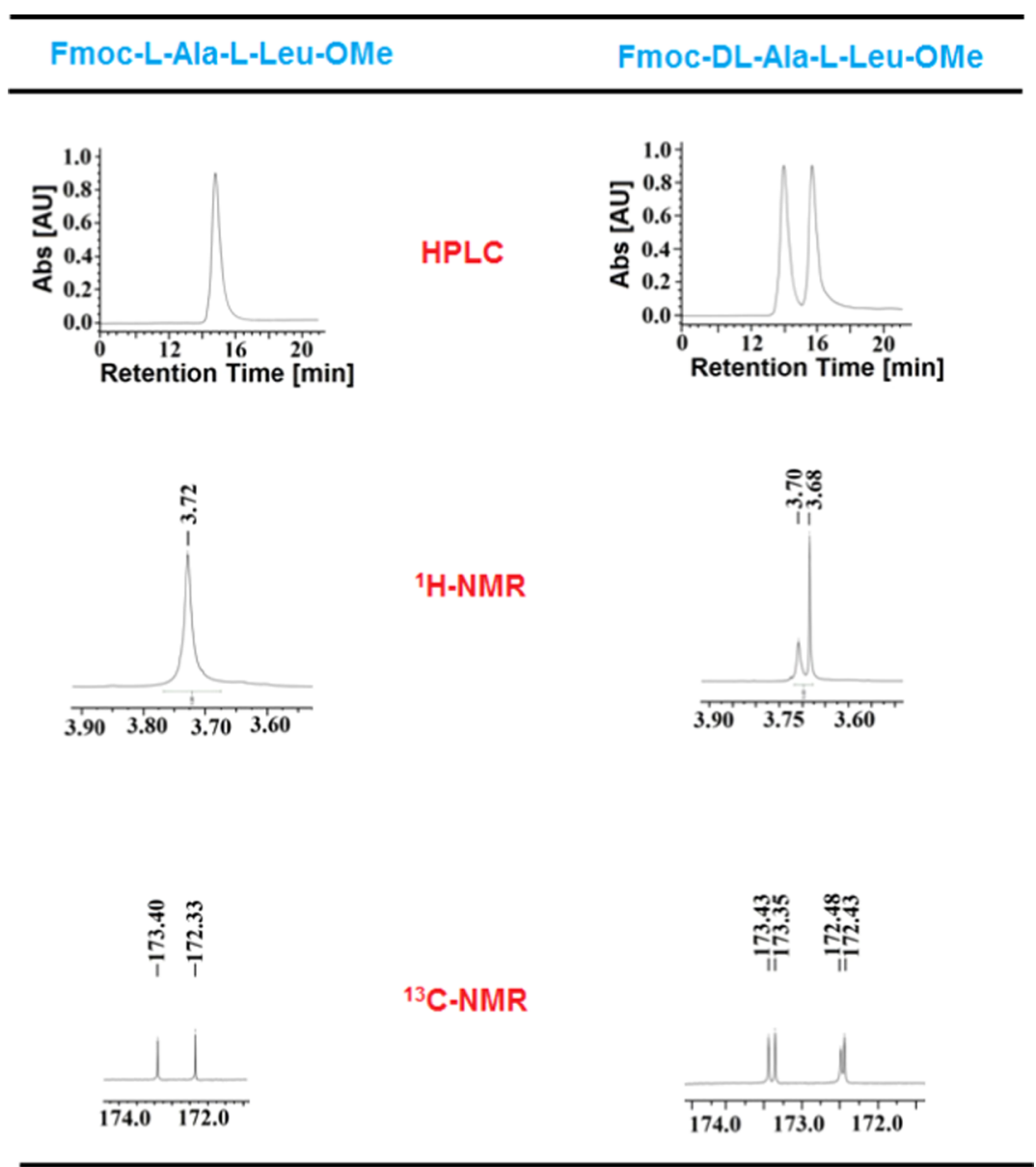

Figure 3. Comparative study of racemization by HPLC, ${ }^{1} \mathrm{H}$ NMR, and ${ }^{13} \mathrm{C}$ NMR of Fmoc-L-Ala-L-Leu-OMe (left panel) and Fmoc-DL-Ala-L-Leu-OMe (right panel).

Table 2. Comparison of the Yield and Racemization of Z-GlyPhe-Val-OMe Synthesized Using Various Coupling Reagents

$\begin{array}{cccc}\text { entry } & \text { coupling reagent } & \text { yield (\%) } & \text { racemization (\%) } \\ 1 & \text { HDMB } & 90 & 2.9 \\ 2 & \text { HDMA } & 90 & 0.7 \\ 3 & \text { HBTU } & 89 & 5.9 \\ 4 & \text { HATU } & 90 & 1.6 \\ 5 & \text { TCBOXY } & 90 & \text { n.d. }^{a} \\ { }^{a} \text { No racemization could be detected. } & \end{array}$

analyses were performed with reversed-phase chromatographic columns and CHIRAL PAK AS-H $\left(5 \mu \mathrm{m}, 4.6 \times 250 \mathrm{~mm}^{2}\right)$ column attached to an UV detector. HPLC analyses were performed with HPLC-grade solvents.

Procedure for the Synthesis of the Coupling Reagent (E)-Ethyl-2-cyano-2-(((2,4,6-trichlorobenzoyl)oxy)imino)acetate (TCBOXY, I). DIPEA (129 mg, 1 equiv) was added to a solution of oxyma (142 mg, 1 equiv) in $2 \mathrm{~mL}$ of DCM under nitrogen. The temperature of the reaction mixture was decreased to $0^{\circ} \mathrm{C}$. Then, 2,4,6-trichlorobenzoyl chloride ( $243 \mathrm{mg}, 1$ equiv) was added dropwise. The mixture was then stirred at room temperature for another $2 \mathrm{~h}$. After completion of the reaction, 10 $\mathrm{mL}$ of $\mathrm{DCM}$ was added to it and washed with $5 \% \mathrm{HCl}(3 \times 5$ $\mathrm{mL})$. Finally, the organic portion was collected, dried using anhydrous $\mathrm{CaCl}_{2}$, and evaporated. The obtained solid mass was recrystallized with hexane. $R_{\mathrm{f}}: 0.50$ (EtOAc/hexane, 1:9); yield $326 \mathrm{mg}$, 94\%; white crystalline solid, mp $83-85{ }^{\circ} \mathrm{C}$; ${ }^{1} \mathrm{H}$ NMR $\left(600 \mathrm{MHz}, \mathrm{CDCl}_{3}\right): \delta 7.47(\mathrm{~s}, 2 \mathrm{H}), 4.54-4.53(\mathrm{q}, J=7.2 \mathrm{~Hz}, 2 \mathrm{H}$, $\left.\mathrm{CH}_{2}\right), 1.47-1.44(\mathrm{t}, J=7.2 \mathrm{~Hz}, 3 \mathrm{H}) ;{ }^{13} \mathrm{C}$ NMR $(150 \mathrm{MHz}$, $\left.\mathrm{CDCl}_{3}\right) \delta 158.7,156.6,138.6,134.0,132.8,128.7,127.9,106.6$, 65.0, 14.1; IR (KBr) 3076, 1806, 1732, 1577, 1375, 1220, 1150, 1087, $990 \mathrm{~cm}^{-1}$; HRMS (ESI) $m / z:[\mathrm{M}+\mathrm{Na}]^{+}$calcd for $\mathrm{C}_{12} \mathrm{H}_{7} \mathrm{C}_{13} \mathrm{~N}_{2} \mathrm{NaO}_{4} 370.9369$, found 370.9367 .

Procedure for the Synthesis of Esters, Thioesters, and Amides. TCBOXY (1 equiv) was added to a DCM $(2 \mathrm{~mL})$ solution of carboxylic acid ( 1 equiv), DMAP ( 0.3 equiv), and DIPEA (1.5 equiv). All of the components were mixed well for 3-5 min for preactivation, and then, alcohol, thiol, or amines (1.2 equiv) was added to it. Then, the mixture was stirred for 5-30 $\mathrm{min}$ at room temperature. After completion of the reaction, the whole mixture was diluted with $20 \mathrm{~mL}$ of ethyl acetate. The organic portions were collected, washed with $5 \% \mathrm{HCl}(3 \times 5 \mathrm{~mL})$ and $5 \% \mathrm{NaHCO}_{3}(3 \times 5 \mathrm{~mL})$, and dried using anhydrous $\mathrm{Na}_{2} \mathrm{SO}_{4}$. Finally, $\mathrm{Na}_{2} \mathrm{SO}_{4}$ was filtered off and the solvent was evaporated to obtain the product, which was purified by column chromatography.

Procedure for the Peptide Synthesis. TCBOXY (1 equiv) was added to a solution of $\mathrm{N}$-protected amino acid (1 equiv), DMAP ( 0.3 equiv), and DIPEA ( 1.5 equiv) in $2 \mathrm{~mL}$ of DCM. The reaction mixture was stirred for 5 min for preactivation, followed by the addition of methyl ester of amino acid (1.5 equiv) and DIPEA (1.5 equiv) in $1 \mathrm{~mL}$ of DCM. The reaction mixture was stirred at room temperature for 20-120 min. After completion of the reaction, the reaction mixture was diluted with $20 \mathrm{~mL}$ of ethyl acetate; the organic phase was washed with 5\% 
Scheme 4. Plausible Mechanism of the Reaction Mediated by I

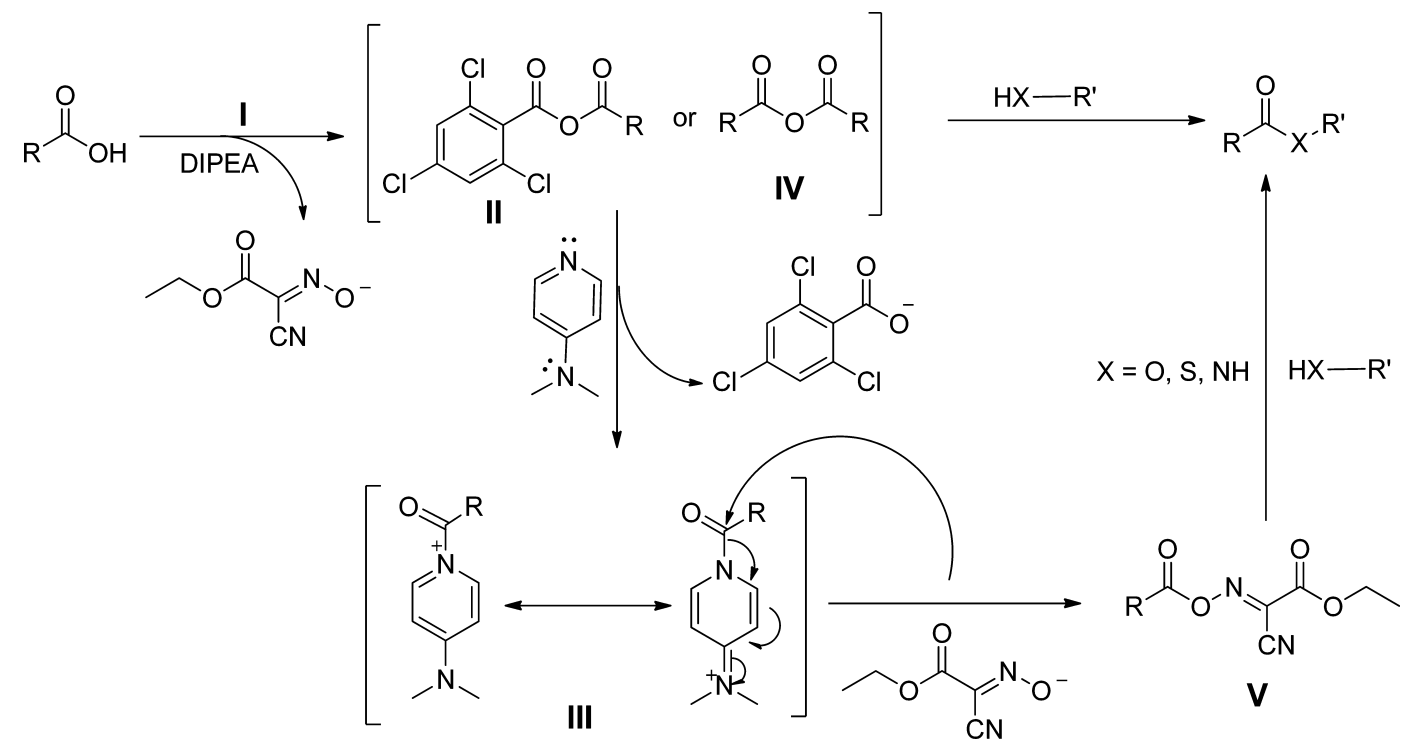

$\mathrm{HCl}(3 \times 5 \mathrm{~mL}), 5 \% \mathrm{NaHCO}_{3}(3 \times 5 \mathrm{~mL})$, and brine; and dried using anhydrous $\mathrm{Na}_{2} \mathrm{SO}_{4}$. Finally, $\mathrm{Na}_{2} \mathrm{SO}_{4}$ was filtered and the solvent was evaporated. The product was purified by silica gel column chromatography.

Solution-Phase Synthesis of Boc-VVIA-OMe. TCBOXY ( 1 equiv) was added to a solution of Boc-Ile-OH ( 1 equiv), DMAP ( 0.3 equiv), and DIPEA ( 1.5 equiv) in $2 \mathrm{~mL}$ of DCM. The reaction mixture was stirred for 5 min for preactivation. In another RB, methyl ester of alanine (1.5 equiv) was taken in DCM and DIPEA was added to it until basic $\mathrm{pH}$ was reached. Finally, this solution was added to the above solution and stirring was continued until completion of the reaction. Then, the reaction mixture was diluted by $20 \mathrm{~mL}$ of EtOAc and washed by $5 \% \mathrm{NaHCO}_{3}$ solution $(2 \times 5 \mathrm{~mL})$ and $5 \%$ citric acid solution $(2$ $\times 5 \mathrm{~mL}$ ). Finally, the combined organic layer was dried using anhydrous $\mathrm{Na}_{2} \mathrm{SO}_{4}$. The solid product (Boc-IA-OMe) was obtained after evaporation of EtOAc by a rotary vacuum evaporator.

In $50 \mathrm{~mL}$ of $\mathrm{RB}$, solid product (Boc-IA-OMe) was taken and TFA/DCM (1:1) mixture was added and stirred up to $2.5 \mathrm{~h}$. After that, TFA was evaporated by a rotary vacuum evaporator, the solution was washed three to four times with diethyl ether, and finally a white solid (IA-OMe) was obtained. After Boc deprotection, the resulting IA-OMe was coupled with Boc-V-OH following the procedure as mentioned earlier to obtain Boc-VIA$\mathrm{OMe}$. Another cycle of Boc-deprotection and coupling with Boc$\mathrm{V}-\mathrm{OH}$ resulted in white solid Boc-VVIA-OMe, which was characterized by reversed-phase HPLC, with a retention time 4 min on a linear gradient of $0-70 \%$ for $0-10 \mathrm{~min}$ and then $70-$ $100 \%$ for $10-25$ min $\mathrm{CH}_{3} \mathrm{CN}$ in $\mathrm{H}_{2} \mathrm{O}$ with $0.1 \%$ formic acid in a symmetry $\mathrm{C} 8$ analytical column. Low-resolution mass spectrometry (LRMS) (ESI) $m / z$ : $[\mathrm{M}+\mathrm{H}]^{+}$calcd for $\mathrm{C}_{25} \mathrm{H}_{47} \mathrm{~N}_{4} \mathrm{O}_{7}$ 515.3445 , found 515.3521 . The yield was $75 \%$ with respect to starting material Boc-isoleucine.

Solid-Phase Synthesis of PGVGVPGVGV-NH $\mathrm{N}_{2}$ and DNASFVEDLG-NH $\mathrm{NH}_{2}$. Decapeptide was manually assembled stepwise on Fmoc Rink Amide MBHA resin by Fmoc/tertbutyl $(t$-Bu) protection strategy. Fmoc amino acids (1.5 equiv), TCBOXY ( 1 equiv), DMAP ( 0.3 equiv), and DIPEA ( 3 equiv) were kept for preactivation for $5 \mathrm{~min}$. Then, amino acid coupling was performed for 2-4 h. Fmoc deprotection was carried out using TFA/DCM (1:1) mixture for $2.5 \mathrm{~h}$. Purification of the peptide was carried out by preparative HPLC, and lyophilization afforded the final peptide.

Solid-Phase Synthesis of Segments of Gramicidin A, B, and $C$. The syntheses were carried out by stepwise coupling of amino acids on Wang resin, as mentioned before, by Fmoc/t-Bu protection strategy. Fmoc amino acids (1.5 equiv), TCBOXY (1 equiv), DMAP ( 0.3 equiv), and DIPEA (3 equiv) were kept for preactivation for $5 \mathrm{~min}$. Then, amino acid coupling was performed for 2-4 h. Fmoc deprotection was carried out using TFA/DCM (1:1) mixture for $2.5 \mathrm{~h}$. Purification of the peptide was carried out by preparative HPLC, and lyophilization afforded the final peptide.

Procedure to Identify $(E)$-ethyl-9-cyano-1-(9H-fluoren9-yl)-5-methyl-3,6-dioxo-2,7-dioxa-4,8-diazadec-8-en10-oate (Intermediate V, Scheme 4). TCBOXY (1 equiv) was added to a solution of Fmoc-Ala-OH ( 1 equiv), DMAP (0.3 equiv), and DIPEA ( 1.5 equiv) in $2 \mathrm{~mL}$ of DCM. The reaction mixture was stirred for $30 \mathrm{~min}$ at room temperature. After 30 min, we observed one spot in TLC. The reaction mixture was diluted with $20 \mathrm{~mL}$ of ethyl acetate; the organic phase was washed with $5 \% \mathrm{HCl}(3 \times 5 \mathrm{~mL}), 5 \% \mathrm{NaHCO}_{3}(3 \times 5 \mathrm{~mL})$, and brine; and dried using anhydrous $\mathrm{Na}_{2} \mathrm{SO}_{4}$. Finally, $\mathrm{Na}_{2} \mathrm{SO}_{4}$ was filtered off and the solvent was evaporated to obtain the intermediate, which was purified by column chromatography. $R_{\mathrm{f}}$ : 0.50 (EtOAc/hexane, 2:8); yield $357 \mathrm{mg}, 82 \%$; white solid, $\mathrm{mp}$ 95-97 ${ }^{\circ} \mathrm{C}$; ${ }^{1} \mathrm{H} \mathrm{NMR}\left(600 \mathrm{MHz}, \mathrm{CDCl}_{3}\right): \delta 7.77-7.76(\mathrm{~d}, J=7.8$ $\mathrm{Hz}, 2 \mathrm{H}), 7.61-7.59(\mathrm{t}, J=6.6 \mathrm{~Hz}, 2 \mathrm{H}), 7.41-7.39(\mathrm{t}, J=7.2 \mathrm{~Hz}$, $2 \mathrm{H}), 7.33-7.31(\mathrm{t}, J=7.2 \mathrm{~Hz}, 2 \mathrm{H}), 5.38($ br s, $1 \mathrm{H}), 4.43-4.36$ $(\mathrm{m}, 3 \mathrm{H}), 4.24-4.20(\mathrm{~m}, 3 \mathrm{H}), 1.44-1.43(\mathrm{~d}, J=7.2 \mathrm{~Hz}, 3 \mathrm{H})$, $1.29-1.28(\mathrm{~m}, 3 \mathrm{H}) ;{ }^{13} \mathrm{C}$ NMR $\left(150 \mathrm{MHz}, \mathrm{CDCl}_{3}\right) \delta 173.3$, $155.8,144.0,141.5,127.9,127.3,125.3,120.2,67.2,61.8,49.9$, $47.4,19.0,14.3$; IR (KBr) 2925, 1747, 1692, 1534, 1450, 1260, $1027,738 \mathrm{~cm}^{-1}$.

Recyclability of the Coupling Reagent, TCBOXY. TCBOXY (1 equiv) was added to a solution of 2-picolinic acid ( 1 equiv), DMAP ( 0.3 equiv) and DIPEA ( 1.5 equiv) in $2 \mathrm{~mL}$ of DCM. The reaction mixture was stirred for 3-5 min for preactivation, followed by the addition of tert-butyl amine (1.2 equiv). The reaction mixture was stirred at room temperature for $45 \mathrm{~min}$. After completion of the reaction, the reaction mixture 
Scheme 5. Recyclability of the Coupling Reagent, TCBOXY Path a

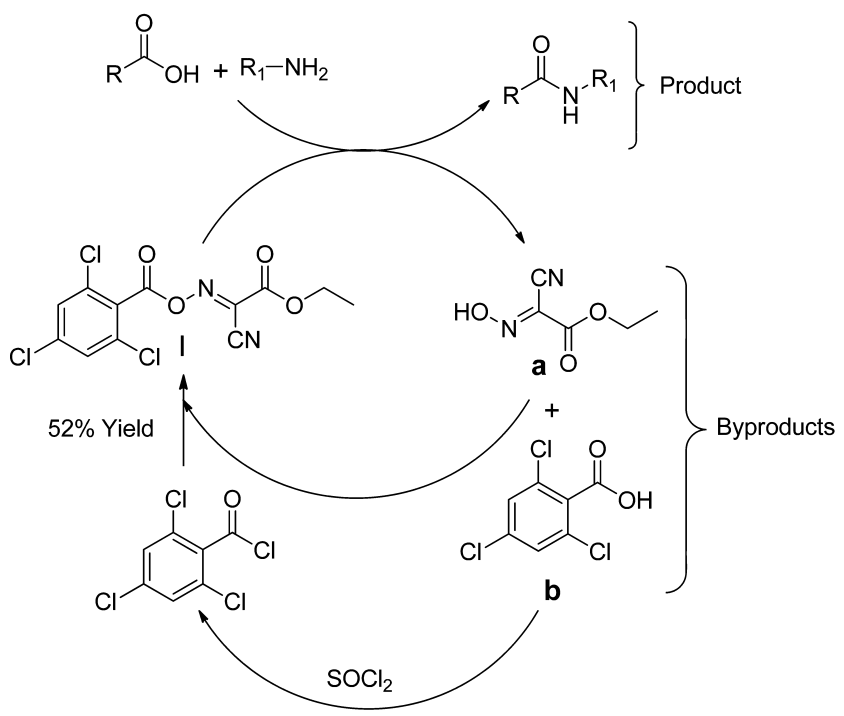

Path b

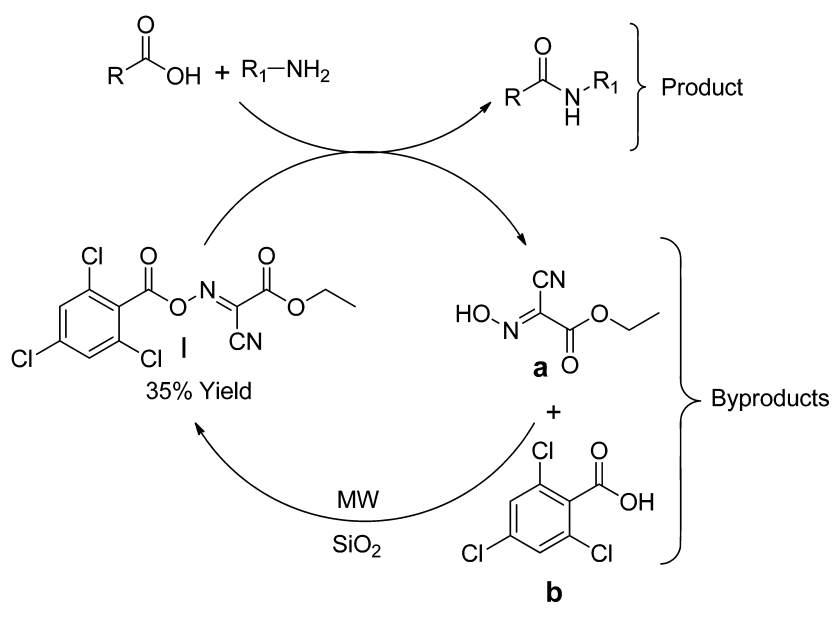

was diluted with ethyl acetate and washed with $5 \% \mathrm{HCl}$ solution $(3 \times 5 \mathrm{~mL})$. The concentrated organic layer was directly purified by silica gel column chromatography. The product and byproducts $\mathbf{a}$ and $\mathbf{b}$ were purified by elution with specific eluents. In path $\mathbf{a}$, the recovered $\mathbf{b}$ was chlorinated with thionyl chloride by heating at $110-114^{\circ} \mathrm{C}$ in toluene for $3 \mathrm{~h}$ and mixed with the recovered oxyma (a) in the presence of DIPEA and I was obtained with $52 \%$ yield. In path $b$, we recovered I by recombination of byproducts $\mathbf{a}$ and $\mathbf{b}$ in the presence of silica gel under microwave irradiation with $35 \%$ yield. The yield of recyclable coupling reagent was calculated with respect to the initial amount of I used in the reaction. By this way, we were able to recover byproducts and recombine to regenerate the coupling reagent (I) very easily.

(S)-Benzyl-2-((( $9 H$-fluoren-9-yl)methoxy)carbonyl)amino)-3-phenylpropanoate (2a). White solid (386 mg, $81 \%) ; R_{\mathrm{f}}=0.50$ (EtOAc/hexane) $2: 8 ; \mathrm{mp} 107-109{ }^{\circ} \mathrm{C} ;{ }^{1} \mathrm{H}$ NMR $\left(600 \mathrm{MHz}, \mathrm{CDCl}_{3}\right) \delta 7.78-7.76(\mathrm{~d}, J=7.8 \mathrm{~Hz}, 2 \mathrm{H}), 7.57-$ $7.55(\mathrm{t}, J=7.2 \mathrm{~Hz}, 2 \mathrm{H}), 7.42-7.39(\mathrm{t}, J=7.8 \mathrm{~Hz}, 2 \mathrm{H}), 7.37-7.22$ (m, 8H), 5.29 (br, 1H), 5.19-5.12 (m, 2H), 4.74-4.71 (m, 1H), $4.45-4.42(\mathrm{~m}, 1 \mathrm{H}), 4.35-4.32(\mathrm{~m}, 1 \mathrm{H}), 4.21-4.19(\mathrm{t}, J=7.2 \mathrm{~Hz}$, $1 \mathrm{H}), 3.15-3.08(\mathrm{~m}, 2 \mathrm{H}) ;{ }^{13} \mathrm{C} \mathrm{NMR}\left(150 \mathrm{MHz}, \mathrm{CDCl}_{3}\right) \delta 171.5$, $155.7,144.0,143.9,141.5,135.7,135.2,129.5,128.8,128.7$, 127.9, 127.3, 127.2, 125.3, 125.2, 120.1, 67.5, 67.1, 55.0, 47.3, 38.3; FT-IR $\left(\mathrm{KBr}, \mathrm{cm}^{-1}\right): 2923,1719,1504,1482,1349,1260$, 1150, 1012, 740, 697; LRMS (ESI) $m / z:[\mathrm{M}+\mathrm{H}]^{+}$calcd for $\mathrm{C}_{31} \mathrm{H}_{28} \mathrm{NO}_{4} 478.2018$, found 478.2002.

DL-(S)-Benzyl-2-((( $9 H$-fluoren-9-yl)methoxy)carbonyl)amino)-3-phenylpropanoate (rac-2a). White solid (382 mg, $80 \%) ; R_{\mathrm{f}}=0.50$ (EtOAc/hexane) $2: 8 ; \mathrm{mp} 107-109{ }^{\circ} \mathrm{C} ;{ }^{1} \mathrm{H}$ $\operatorname{NMR}\left(600 \mathrm{MHz}, \mathrm{CDCl}_{3}\right) \delta 7.78-7.76(\mathrm{~d}, J=7.8 \mathrm{~Hz}, 2 \mathrm{H}), 7.57-$ $7.55(\mathrm{t}, J=7.2 \mathrm{~Hz}, 2 \mathrm{H}), 7.42-7.39(\mathrm{t}, J=7.8 \mathrm{~Hz}, 2 \mathrm{H}), 7.37-7.22$ $(\mathrm{m}, 8 \mathrm{H}), 5.29(\mathrm{br}, 1 \mathrm{H}), 5.20-5.13(\mathrm{~m}, 2 \mathrm{H}), 4.74-4.71(\mathrm{~m}, 1 \mathrm{H})$, $4.45-4.42(\mathrm{~m}, 1 \mathrm{H}), 4.35-4.32(\mathrm{~m}, 1 \mathrm{H}), 4.21-4.19(\mathrm{t}, J=7.2 \mathrm{~Hz}$, $1 \mathrm{H}), 3.15-3.08(\mathrm{~m}, 2 \mathrm{H}) ;{ }^{13} \mathrm{C} \mathrm{NMR}\left(150 \mathrm{MHz}, \mathrm{CDCl}_{3}\right) \delta 171.5$, $155.7,143.9,141.5,135.7,135.2,129.6,128.8,127.9$, 127.3, $127.2,125.3,125.2,120.2,67.5,67.2,55.0,47.4,38.4$; FT-IR $\left(\mathrm{KBr}, \mathrm{cm}^{-1}\right): 2923,1719,1504,1482,1349,1260,1150,1012$, 740, 697; LRMS (ESI) $m / z$ : $[\mathrm{M}+\mathrm{H}]^{+}$calcd for $\mathrm{C}_{31} \mathrm{H}_{28} \mathrm{NO}_{4}$ 478.2018, found 478.1996 .

(S)-Benzyl-2-((( $9 H$-fluoren-9-yl)methoxy)carbonyl)amino)-3-methylbutanoate (2b). White solid (352 mg, $82 \%) ; R_{\mathrm{f}}=0.50$ (EtOAc/hexane) 2:8; mp 86-89 ${ }^{\circ} \mathrm{C} ;{ }^{1} \mathrm{H}$ $\operatorname{NMR}\left(600 \mathrm{MHz}, \mathrm{CDCl}_{3}\right) \delta 7.78-7.77(\mathrm{~d}, J=7.2 \mathrm{~Hz}, 2 \mathrm{H}), 7.61-$ $7.60(\mathrm{~d}, J=7.2 \mathrm{~Hz}, 2 \mathrm{H}), 7.42-7.40(\mathrm{t}, J=7.2 \mathrm{~Hz}, 2 \mathrm{H}), 7.36-7.31$ $(\mathrm{m}, 3 \mathrm{H}), 5.35(\mathrm{br}, 1 \mathrm{H}), 5.23-5.15(\mathrm{~m}, 2 \mathrm{H}), 4.41-4.36(\mathrm{~m}, 3 \mathrm{H})$, $4.25-4.22(\mathrm{t}, J=7.2 \mathrm{~Hz}, 1 \mathrm{H}), 2.23-2.18(\mathrm{~m}, 1 \mathrm{H}), 0.96-0.95(\mathrm{~d}$, $J=6.6 \mathrm{~Hz}, 3 \mathrm{H}), 0.88-0.87(\mathrm{~d}, J=7.2 \mathrm{~Hz}, 3 \mathrm{H}) ;{ }^{13} \mathrm{C}$ NMR $(150$ $\left.\mathrm{MHz}, \mathrm{CDCl}_{3}\right) \delta 172.2$, 156.4, 144.1, 143.9, 141.5, 135.5, 128.8, $128.7,128.6,127.9,127.2,125.3,120.2,67.3,67.2,59.2,47.4$, 31.5 , 19.2, 17.7; FT-IR $\left(\mathrm{KBr}, \mathrm{cm}^{-1}\right): 2925,1744,1689,1530$, 1449, 1270, 1156, 1030, 736, 696; HRMS (ESI) $m / z:[\mathrm{M}+\mathrm{H}]^{+}$ calcd for $\mathrm{C}_{27} \mathrm{H}_{28} \mathrm{NO}_{4} 430.2018$, found 430.2018 .

Benzyl-2-((( $(9 H$-fluoren-9-yl)methoxy)carbonyl)amino)-2-methylpropanoate (2c). Yellow solid (324 mg, $78 \%) ; R_{\mathrm{f}}=0.50$ (EtOAc/hexane) $2: 8 ; \mathrm{mp} 68-70{ }^{\circ} \mathrm{C} ;{ }^{1} \mathrm{H} \mathrm{NMR}$ $\left(600 \mathrm{MHz}, \mathrm{CDCl}_{3}\right) \delta 7.78-7.76(\mathrm{~d}, J=7.8 \mathrm{~Hz}, 2 \mathrm{H}), 7.59-7.58$ $(\mathrm{d}, J=7.2 \mathrm{~Hz}, 2 \mathrm{H}), 7.42-7.39(\mathrm{t}, J=7.2 \mathrm{~Hz}, 2 \mathrm{H}), 7.32-7.30(\mathrm{t}, J$ $=7.2 \mathrm{~Hz}, 3 \mathrm{H}), 5.45(\mathrm{br}, 1 \mathrm{H}), 5.18(\mathrm{~s}, 2 \mathrm{H}), 4.35(\mathrm{~s}, 2 \mathrm{H}), 4.19(\mathrm{~s}$, $1 \mathrm{H}), 1.59(\mathrm{~s}, 6 \mathrm{H}) ;{ }^{13} \mathrm{C} \mathrm{NMR}\left(150 \mathrm{MHz}, \mathrm{CDCl}_{3}\right) \delta 174.6,155.1$, $144.1,141.4,135.7,128.7,128.4,128.1,127.8,127.2,125.2$, 120.1, 67.4, 66.7, 56.7, 47.3, 25.2; FT-IR $\left(\mathrm{KBr}, \mathrm{cm}^{-1}\right): 2987$, $1736,1693,1537,1450,1386,1277,1143,1107,743,696$; HRMS (ESI) $m / z:[\mathrm{M}+\mathrm{H}]^{+}$calcd for $\mathrm{C}_{26} \mathrm{H}_{26} \mathrm{NO}_{4} 416.1862$, found 416.1864 .

(2S, 3R)-4-Nitrophenyl-2-((tert-butoxycarbonyl)amino)-3-methylpentanoate (2d). Yellow liquid (299 mg, $85 \%) ; R_{\mathrm{f}}=0.50$ (EtOAc/hexane) $2: 8 ;{ }^{1} \mathrm{H}$ NMR $(600 \mathrm{MHz}$, $\left.\mathrm{CDCl}_{3}\right) \delta 8.29-8.28(\mathrm{~d}, J=9.0 \mathrm{~Hz}, 2 \mathrm{H}), 7.30-7.29(\mathrm{~d}, J=9.0$ $\mathrm{Hz}, 2 \mathrm{H}), 5.09(\mathrm{br}, 1 \mathrm{H}), 4.51-4.48(\mathrm{q}, 1 \mathrm{H}), 1.58-1.54(\mathrm{~m}, 1 \mathrm{H})$, 1.47 (s, 9H), $1.33-1.29(\mathrm{~m}, 2 \mathrm{H}), 1.08-1.07(\mathrm{~d}, J=7.2 \mathrm{~Hz}, 3 \mathrm{H})$, $1.01-0.99(\mathrm{t}, J=7.2 \mathrm{~Hz}, 3 \mathrm{H}) ;{ }^{13} \mathrm{C} \mathrm{NMR}\left(150 \mathrm{MHz}, \mathrm{CDCl}_{3}\right) \delta$ $170.6,156.0,155.3,145.7,126.4,125.5,122.6,115.8,80.8,58.5$, 38.0, 28.5, 25.4, 15.9, 11.8; FT-IR $\left(\mathrm{KBr}, \mathrm{cm}^{-1}\right): 2973,2879$, $1765,1691,1583,1367,1162,1045,853,629$; HRMS (ESI) $m / z$ : $[\mathrm{M}+\mathrm{H}]^{+}$calcd for $\mathrm{C}_{17} \mathrm{H}_{25} \mathrm{~N}_{2} \mathrm{O}_{6} 353.1713$, found 353.1716.

Prop-2-yn-1-yl-quinoline-2-carboxylate (2e). Brown solid (188 mg, 89\%); $R_{\mathrm{f}}=0.50$ (EtOAc/hexane) 2:8; mp 104-107 ${ }^{\circ} \mathrm{C}$; ${ }^{1} \mathrm{H}$ NMR $\left(600 \mathrm{MHz}, \mathrm{CDCl}_{3}\right) \delta 8.34-8.31(\mathrm{t}, J=$ $7.8 \mathrm{~Hz}, 2 \mathrm{H}), 8.23-8.22(\mathrm{~d}, J=8.4 \mathrm{~Hz}, 1 \mathrm{H}), 7.90-7.89(\mathrm{~d}, J=7.8$ $\mathrm{Hz}, 1 \mathrm{H}), 7.82-7.79(\mathrm{t}, J=7.8 \mathrm{~Hz}, 1 \mathrm{H}), 7.68-7.66(\mathrm{t}, J=7.2 \mathrm{~Hz}$, $1 \mathrm{H}), 5.08(\mathrm{~s}, 2 \mathrm{H}), 2.56-2.55(\mathrm{t}, J=2.4 \mathrm{~Hz}, 1 \mathrm{H}) ;{ }^{13} \mathrm{C}$ NMR $(150$ $\left.\mathrm{MHz}, \mathrm{CDCl}_{3}\right) \delta 164.8,147.8,147.4,137.6,131.0,130.6,129.7$, 
129.1, 127.8, 121.3, 77.5, 75.7, 53.7; FT-IR $\left(\mathrm{KBr}, \mathrm{cm}^{-1}\right):$ 2924, 2854, 2127, 1716, 1461, 1372, 1209, 1134, 781, 624; HRMS (ESI) $m / z:[\mathrm{M}+\mathrm{H}]^{+}$calcd for $\mathrm{C}_{13} \mathrm{H}_{10} \mathrm{NO}_{2}$ 212.0712, found 212.1075

(E)-But-2-en-1-yl-2-naphthoate (2f). Yellow liquid (206 $\mathrm{mg}, 91 \%) ; R_{\mathrm{f}}=0.50$ (EtOAc/hexane) $2: 8 ;{ }^{1} \mathrm{H}$ NMR $(600 \mathrm{MHz}$, $\left.\mathrm{CDCl}_{3}\right) \delta 8.62(\mathrm{~s}, 1 \mathrm{H}), 8.08-8.07(\mathrm{~m}, 1 \mathrm{H}), 7.96-7.95(\mathrm{~d}, J=7.8$ $\mathrm{Hz}, 1 \mathrm{H}), 7.89-7.87(\mathrm{~d}, J=8.4 \mathrm{~Hz}, 2 \mathrm{H}), 7.60-7.53(\mathrm{~m}, 2 \mathrm{H})$, $5.95-5.90(\mathrm{~m}, 1 \mathrm{H}), 5.79-5.75(\mathrm{~m}, 1 \mathrm{H}), 4.83-4.82(\mathrm{~d}, J=6.6$ $\mathrm{Hz}, 2 \mathrm{H}), 1.79-1.78$ (d, $J=6.6 \mathrm{~Hz}, 3 \mathrm{H}) ;{ }^{13} \mathrm{C}$ NMR $(150 \mathrm{MHz}$, $\left.\mathrm{CDCl}_{3}\right) \delta 166.7,135.6,132.6,131.6,131.2,129.5,128.3,128.2$, 127.9, 127.7, 126.7, 125.4, 125.3, 65.9, 18.0; FT-IR $\left(\mathrm{KBr}, \mathrm{cm}^{-1}\right)$ : 3024, 2939, 1716, 1631, 1510, 1446, 1281, 1227, 1195, 1094, 963, 779, 474; HRMS (ESI) $m / z$ : $[\mathrm{M}+\mathrm{H}]^{+}$calcd for $\mathrm{C}_{15} \mathrm{H}_{15} \mathrm{O}_{2}$ 227.1072, found 227.1075.

Furan-2-ylmethyl-2-phenylacetate (2g). Black liquid $(189 \mathrm{mg}, 87 \%) ; R_{\mathrm{f}}=0.50$ (EtOAc/hexane) $2: 8 ;{ }^{1} \mathrm{H}$ NMR (600 $\left.\mathrm{MHz} \mathrm{CDCl}_{3}\right) \delta 7.40-7.39(\mathrm{~m}, 1 \mathrm{H}), 7.32-7.24(\mathrm{~m}, 5 \mathrm{H}), 6.37-$ $6.32(\mathrm{~m}, 2 \mathrm{H}), 5.06(\mathrm{~s}, 2 \mathrm{H}), 3.62(\mathrm{~s}, 2 \mathrm{H}) ;{ }^{13} \mathrm{C}$ NMR $(100 \mathrm{MHz}$, $\left.\mathrm{CDCl}_{3}\right) \delta 171.3,149.4,143.4,133.8,129.4,128.7,127.2,110.8$, 110.7, 58.5, 41.1; FT-IR (KBr, cm $\left.{ }^{-1}\right): 3031,2927,1734,1604$, 1497, 1245, 1151, 700, 600; HRMS (ESI) $m / z:[\mathrm{M}+\mathrm{H}]^{+}$calcd for $\mathrm{C}_{13} \mathrm{H}_{13} \mathrm{O}_{3} 217.0865$, found 217.0863 .

(1R, 2S, 5R)-2-lsopropyl-5-methylcyclohexyl Picolinate (2h). Brown liquid (196 mg, 75\%); $R_{\mathrm{f}}=0.50$ (EtOAc/hexane) 2:8; H NMR (600 MHz, $\left.\mathrm{CDCl}_{3}\right) \delta 8.79-8.78(\mathrm{~d}, J=4.2 \mathrm{~Hz}$, $1 \mathrm{H}), 8.11-8.09$ (d, $J=7.8 \mathrm{~Hz}, 1 \mathrm{H}), 7.47-7.46(\mathrm{~m}, 1 \mathrm{H}), 5.03-$ $4.99(\mathrm{~m}, 1 \mathrm{H}), 1.96-1.91(\mathrm{~m}, 1 \mathrm{H}), 1.72-1.52(\mathrm{~m}, 4 \mathrm{H}), 1.26-$ $1.07(\mathrm{~m}, 4 \mathrm{H}), 0.90-0.87(\mathrm{~m}, 6 \mathrm{H}), 0.77-0.75(\mathrm{~m}, 3 \mathrm{H}) ;{ }^{13} \mathrm{C}$ NMR $\left(150 \mathrm{MHz}, \mathrm{CDCl}_{3}\right) \delta 164.8,150.0,148.6,137.2,126.9$, 125.3, 76.1, 47.1, 40.9, 34.4, 31.7, 26.5, 23.6, 22.2, 20.9, 16.5; FTIR $\left(\mathrm{KBr}, \mathrm{cm}^{-1}\right): 2955,2870,1713,1584,1456,1306,1244,1133$, 1087, 748, 707, 619; LRMS (ESI) $m / z:[\mathrm{M}+\mathrm{H}]^{+}$calcd for $\mathrm{C}_{16} \mathrm{H}_{24} \mathrm{NO}_{2}$ 262.1807, found 262.2001.

3-Bromophenyl-quinoline-2-carboxylate (2i). Liquid (271 mg, 83\%); $R_{\mathrm{f}}=0.50$ (EtOAc/hexane) $2: 8 ;{ }^{1} \mathrm{H}$ NMR (400 $\left.\mathrm{MHz}, \mathrm{CDCl}_{3}\right) \delta 8.43-8.41(\mathrm{~d}, J=8.4 \mathrm{~Hz}, 1 \mathrm{H}), 8.32-8.29(\mathrm{~m}$, $2 \mathrm{H}), 7.94-7.92(\mathrm{~d}, J=8.4 \mathrm{~Hz}, 1 \mathrm{H}), 7.81-7.77(\mathrm{t}, J=7.2 \mathrm{~Hz}$, $1 \mathrm{H}), 7.71-7.68(\mathrm{t}, J=7.2 \mathrm{~Hz}, 1 \mathrm{H}), 7.38-7.36(\mathrm{~m}, 2 \mathrm{H}), 7.25-$ $7.21(\mathrm{t}, J=7.6 \mathrm{~Hz}, 1 \mathrm{H}), 7.17-7.14(\mathrm{~m}, 1 \mathrm{H}) ;{ }^{13} \mathrm{C}$ NMR $(100$ $\left.\mathrm{MHz} \mathrm{CDCl}_{3}\right) \delta 156.7,150.9,147.1,146.2,138.9,131.7,130.9$, $129.7,128.0,125.0,123.6,122.8,121.5,120.4,119.0,114.5$; FTIR $\left(\mathrm{KBr}, \mathrm{cm}^{-1}\right): 2924,1650,1582,1472,1351,1250,1062,994$, $863,770,679$.

(E)-Prop-2-yn-1-yl 3-(4-methoxyphenyl)acrylate (2j). Liquid (197 mg, 91\%); $R_{\mathrm{f}}=0.50$ (EtOAc/hexane) $2: 8 ;{ }^{1} \mathrm{H}$ $\operatorname{NMR}\left(400 \mathrm{MHz}, \mathrm{CDCl}_{3}\right) \delta 7.64-7.60(\mathrm{~d}, J=16 \mathrm{~Hz}, 1 \mathrm{H}), 7.41-$ $7.39(\mathrm{~d}, J=8.8 \mathrm{~Hz}, 2 \mathrm{H}), 6.84-6.82(\mathrm{~d}, J=8.8 \mathrm{~Hz}, 2 \mathrm{H}), 6.28-$ $6.24(\mathrm{~d}, J=16 \mathrm{~Hz}, 1 \mathrm{H}), 4.75-4.74(\mathrm{~d}, J=2.4 \mathrm{~Hz}, 2 \mathrm{H}), 3.75(\mathrm{~s}$, $3 \mathrm{H}), 2.52-2.50(\mathrm{t}, J=2.4 \mathrm{~Hz}, 1 \mathrm{H}) ;{ }^{13} \mathrm{C} \mathrm{NMR}(100 \mathrm{MHz}$, $\left.\mathrm{CDCl}_{3}\right) \delta 166.2,161.5,145.5,129.9,126.8,114.3,78.0,74.9$, 55.3, 51.8; FT-IR $\left(\mathrm{KBr}, \mathrm{cm}^{-1}\right): 3290,2937,2839,2128,1714$, $1633,1512,1424,1252,1156,1031,828,551$; HRMS (ESI) $m / z$ : $[\mathrm{M}+\mathrm{H}]^{+}$calcd for $\mathrm{C}_{13} \mathrm{H}_{13} \mathrm{O}_{3} 217.0865$, found 217.0863.

(S)-S-Phenyl-2-(((9H-fluoren-9-yl)methoxy)carbonyl)amino)-3-methylbutanethioate (2k). Solid (392 mg, 91\%); $R_{\mathrm{f}}=0.50$ (EtOAc/hexane) $2: 8 ; \mathrm{mp} 127-129{ }^{\circ} \mathrm{C} ;{ }^{1} \mathrm{H}$ NMR $(600$ $\left.\mathrm{MHz}, \mathrm{CDCl}_{3}\right) \delta 7.75-7.74(\mathrm{~d}, J=7.2 \mathrm{~Hz}, 3 \mathrm{H}), 7.62-7.59(\mathrm{t}, J=$ $7.2 \mathrm{~Hz}, 2 \mathrm{H}), 7.40-7.36(\mathrm{~m}, 5 \mathrm{H}), 7.31-7.28(\mathrm{t}, J=7.2 \mathrm{~Hz}, 3 \mathrm{H})$, $5.28(\mathrm{br}, 1 \mathrm{H}), 4.53-4.50(\mathrm{~m}, 1 \mathrm{H}), 4.47-4.40(\mathrm{~m}, 2 \mathrm{H}), 4.25-$ $4.23(\mathrm{t}, J=6.6 \mathrm{~Hz}, 1 \mathrm{H}), 2.36-2.30(\mathrm{~m}, 1 \mathrm{H}), 1.01-1.00(\mathrm{~d}, J=6.6$ $\mathrm{Hz}, 3 \mathrm{H}), 0.92-0.91$ (d, $J=7.2 \mathrm{~Hz}, 3 \mathrm{H}) ;{ }^{13} \mathrm{C}$ NMR (150 MHz, $\left.\mathrm{CDCl}_{3}\right) \delta 199.0,156.4,144.0,143.9,141.6,134.8,129.8,129.5$,
128.0, 127.3, 127.2, 125.3, 120.2, 67.4, 65.9, 47.5, 31.4, 19.7, 17.1; FT-IR $\left(\mathrm{KBr}, \mathrm{cm}^{-1}\right): 2925,1726,1674,1527,1450,1225,1104$, 1009, 741, 689; HRMS (ESI) $m / z:[\mathrm{M}+\mathrm{H}]^{+}$calcd for $\mathrm{C}_{26} \mathrm{H}_{26} \mathrm{NO}_{3} \mathrm{~S} 432.1633$, found 432.1620 .

S-p-Tolyl-4-methylbenzothioate (2l). Solid (225 mg, 93\%); $R_{\mathrm{f}}=0.50$ (EtOAc/hexane) $2: 8 ; \mathrm{mp} 121-123{ }^{\circ} \mathrm{C} ;{ }^{1} \mathrm{H}$ $\operatorname{NMR}\left(600 \mathrm{MHz}, \mathrm{CDCl}_{3}\right) \delta 7.93-7.91(\mathrm{~d}, J=7.8 \mathrm{~Hz}, 2 \mathrm{H}), 7.39-$ $7.38(\mathrm{~d}, J=7.8 \mathrm{~Hz}, 2 \mathrm{H}), 7.28-7.25(\mathrm{t}, J=7.2 \mathrm{~Hz}, 4 \mathrm{H}), 2.42(\mathrm{~s}$, $3 \mathrm{H}), 2.40$ (s, 3H); ${ }^{13} \mathrm{C}$ NMR $\left(150 \mathrm{MHz}, \mathrm{CDCl}_{3}\right) \delta 190.4,144.7$, 139.9, 135.3, 134.3, 130.3, 129.6, 127.7, 124.1, 21.9, 21.6; FT-IR $\left(\mathrm{KBr}, \mathrm{cm}^{-1}\right): 2920,1666,1602,1401,1204,1172,904,811,717$, 624; HRMS (ESI) $m / z$ : $[\mathrm{M}+\mathrm{H}]^{+}$calcd for $\mathrm{C}_{15} \mathrm{H}_{15} \mathrm{OS} 243.0844$, found 243.0843 .

S-p-Tolyl-2-nitrobenzothioate (2m). Brown solid (235 $\mathrm{mg}, 86 \%) ; R_{\mathrm{f}}=0.50$ (EtOAc/hexane) $2: 8 ; \mathrm{mp} 112-115^{\circ} \mathrm{C} ;{ }^{1} \mathrm{H}$ $\operatorname{NMR}\left(600 \mathrm{MHz}, \mathrm{CDCl}_{3}\right) \delta 8.09-8.08(\mathrm{~d}, J=7.8 \mathrm{~Hz}, 1 \mathrm{H}), 7.74-$ $7.72(\mathrm{t}, J=7.8 \mathrm{~Hz}, 1 \mathrm{H}), 7.68-7.64(\mathrm{~m}, 2 \mathrm{H}), 7.46-7.44(\mathrm{~d}, J=8.4$ $\mathrm{Hz}, 2 \mathrm{H}), 7.28-7.27$ (d, $J=7.8 \mathrm{~Hz}, 2 \mathrm{H}), 2.40(\mathrm{~s}, 3 \mathrm{H}) ;{ }^{13} \mathrm{C} \mathrm{NMR}$ $\left(150 \mathrm{MHz}, \mathrm{CDCl}_{3}\right) \delta 190.9,146.3,140.7,135.0,134.9,133.8$, $131.7,130.5,128.6,124.9,123.2,21.6$; FT-IR $\left(\mathrm{KBr}, \mathrm{cm}^{-1}\right): 2879$, 1694, 1532, 1350, 1204, 1104, 904, 618; HRMS (ESI) $m / z:[\mathrm{M}+$ $\mathrm{H}]^{+}$calcd for $\mathrm{C}_{14} \mathrm{H}_{12} \mathrm{NO}_{3} \mathrm{~S} 274.0538$, found 274.0534 .

S-(4-Nitrophenyl)-4-methylbenzothioate (2n). White solid (224 mg, 82\%); $R_{\mathrm{f}}=0.50$ (EtOAc/hexane) 2:8; mp $118-120{ }^{\circ} \mathrm{C}$; ${ }^{1} \mathrm{H}$ NMR $\left(600 \mathrm{MHz}, \mathrm{CDCl}_{3}\right) \delta 8.29-8.28(\mathrm{~d}, J=$ $8.4 \mathrm{~Hz}, 2 \mathrm{H}), 7.92-7.91(\mathrm{~d}, J=8.4 \mathrm{~Hz}, 2 \mathrm{H}), 7.71-7.70(\mathrm{~d}, J=9.0$ $\mathrm{Hz}, 2 \mathrm{H}), 7.32-7.31$ (d, $J=7.8 \mathrm{~Hz}, 2 \mathrm{H}), 2.45(\mathrm{~s}, 3 \mathrm{H}) ;{ }^{13} \mathrm{C}$ NMR $\left(150 \mathrm{MHz}, \mathrm{CDCl}_{3}\right) \delta 187.7,148.4,145.6,136.6,135.6,133.6$, 129.8, 127.9, 124.1, 22.0; FT-IR (KBr, cm $\left.{ }^{-1}\right): 2923,2852$, 1673, $1598,1518,1345,1261,1025,904,811,742,636$; HRMS (ESI) $m / z:[\mathrm{M}+\mathrm{H}]^{+}$calcd for $\mathrm{C}_{14} \mathrm{H}_{12} \mathrm{NO}_{3} \mathrm{~S}$ 274.0538, found 274.0533.

2-Nitro- $\mathrm{N}$-phenylbenzamide (2o). Brown solid (191 mg, $79 \%) ; R_{\mathrm{f}}=0.50$ (EtOAc/hexane) $2: 8 ; \mathrm{mp} 140-143{ }^{\circ} \mathrm{C} ;{ }^{1} \mathrm{H}$ NMR $\left(400 \mathrm{MHz}, \mathrm{CDCl}_{3}\right) \delta 8.03-8.01(\mathrm{~d}, J=8.0 \mathrm{~Hz}, 1 \mathrm{H}), 7.67-$ $7.63(\mathrm{t}, J=7.2 \mathrm{~Hz}, 1 \mathrm{H}), 7.56-7.54(\mathrm{~d}, J=7.6 \mathrm{~Hz}, 4 \mathrm{H}), 7.33-7.29$ $(\mathrm{t}, J=7.6 \mathrm{~Hz}, 2 \mathrm{H}), 7.15-7.11(\mathrm{t}, J=7.6 \mathrm{~Hz}, 1 \mathrm{H}) ;{ }^{13} \mathrm{C} \mathrm{NMR}(100$ $\left.\mathrm{MHz}, \mathrm{CDCl}_{3}\right) \delta 165.1,146.2,137.8,134.0,133.0,130.6,129.1$, 128.9, 125.0, 124.5, 120.6, 120.5; FT-IR $\left(\mathrm{KBr}, \mathrm{cm}^{-1}\right): 2924$, 2854, 1655, 1599, 1442, 1346, 1258, 856, 788, 588; HRMS (ESI) $m / z:[\mathrm{M}+\mathrm{H}]^{+}$calcd for $\mathrm{C}_{13} \mathrm{H}_{11} \mathrm{~N}_{2} \mathrm{O}_{3} 243.0770$, found 243.0769.

$\mathrm{N}$-Cyclopropyl-4-methoxybenzamide (2p). White solid $(157 \mathrm{mg}, 82 \%) ; R_{\mathrm{f}}=0.50$ (EtOAc/hexane) $2: 8 ; \mathrm{mp} 123-125^{\circ} \mathrm{C}$; ${ }^{1} \mathrm{H}$ NMR $\left(600 \mathrm{MHz}, \mathrm{CDCl}_{3}\right) \delta 7.72-7.70(\mathrm{~d}, J=8.4 \mathrm{~Hz}, 2 \mathrm{H})$, 6.86 (br s, $1 \mathrm{H}), 6.81-6.79(\mathrm{~d}, J=8.8 \mathrm{~Hz}, 2 \mathrm{H}), 3.76(\mathrm{~s}, 3 \mathrm{H})$, $2.83-2.78(\mathrm{~m}, 1 \mathrm{H}), 0.76-0.71(\mathrm{~m}, 2 \mathrm{H}), 0.59-0.55(\mathrm{~m}, 2 \mathrm{H}) ;{ }^{13} \mathrm{C}$ $\mathrm{NMR}\left(150 \mathrm{MHz}, \mathrm{CDCl}_{3}\right) \delta 168.7,162.1,128.9,126.8,113.6$, 55.4, 23.2, 6.6; FT-IR $\left(\mathrm{KBr}, \mathrm{cm}^{-1}\right): 3005,2839,2058,1624$, 1504, 1324, 1311, 1176, 958, 845, 770; HRMS (ESI) $m / z$ : $[\mathrm{M}+$ $\mathrm{H}]^{+}$calcd for $\mathrm{C}_{11} \mathrm{H}_{14} \mathrm{NO}_{2}$ 192.1025, found 192.1026.

4-Methyl-N-(prop-2-yn-1-yl)benzamide (2q). White solid (147 mg, 85\%); $R_{\mathrm{f}}=0.50$ (EtOAc/hexane) 2:8; mp 117-119 ${ }^{\circ} \mathrm{C}$; ${ }^{1} \mathrm{H}$ NMR (400 MHz, $\mathrm{CDCl}_{3}$ ) $\delta 7.70-7.68$ (d, $J=$ $8.4 \mathrm{~Hz}, 2 \mathrm{H}), 7.19-7.17(\mathrm{~d}, J=8.0 \mathrm{~Hz}, 2 \mathrm{H}), 6.82($ br s, $1 \mathrm{H})$, $4.21-4.19(\mathrm{q}, 2 \mathrm{H}), 2.36(\mathrm{~s}, 3 \mathrm{H}), 2.25-2.23(\mathrm{t}, J=2.8 \mathrm{~Hz}, 1 \mathrm{H})$; ${ }^{13} \mathrm{C} \mathrm{NMR}\left(100 \mathrm{MHz}, \mathrm{CDCl}_{3}\right) \delta 167.4,142.3,131.0,129.3,127.2$, 79.9, 71.7, 29.8, 21.6; FT-IR ( $\left.\mathrm{KBr}, \mathrm{cm}^{-1}\right):$ 2926, 1919, 1639, $1545,1416,1309,1258,1122,840,751,654,565$; HRMS (ESI) $m / z:[\mathrm{M}+\mathrm{H}]^{+}$calcd for $\mathrm{C}_{11} \mathrm{H}_{12} \mathrm{NO}_{2}$ 174.0919, found 174.0914.

$\mathrm{N}$-Butylquinoline-2-carboxamide (2r). Brown liquid (198 $\mathrm{mg}, 87 \%) ; R_{\mathrm{f}}=0.50$ (EtOAc/hexane) $2: 8 ;{ }^{1} \mathrm{H}$ NMR $(600 \mathrm{MHz}$, $\left.\mathrm{CDCl}_{3}\right) \delta 8.31-8.28(\mathrm{~m}, 2 \mathrm{H}), 8.10-8.09(\mathrm{~d}, J=8.4 \mathrm{~Hz}, 1 \mathrm{H})$, $7.87-7.85(\mathrm{~d}, J=7.8 \mathrm{~Hz}, 1 \mathrm{H}), 7.76-7.74(\mathrm{t}, J=7.2 \mathrm{~Hz}, 1 \mathrm{H})$, 
$7.61-7.59(\mathrm{t}, J=7.2 \mathrm{~Hz}, 1 \mathrm{H}), 3.55-3.51(\mathrm{~m}, 2 \mathrm{H}), 1.70-1.65(\mathrm{~m}$, $2 \mathrm{H}), 1.49-1.42(\mathrm{~m}, 2 \mathrm{H}), 0.98-0.96(\mathrm{t}, J=7.2 \mathrm{~Hz}, 3 \mathrm{H}) ;{ }^{13} \mathrm{C}$ NMR $\left(150 \mathrm{MHz}, \mathrm{CDCl}_{3}\right) \delta 164.5,150.0,146.5,137.5,130.1$, 129.7, 129.3, 127.9, 127.8, 118.9, 39.4, 31.9, 20.3, 13.9; FT-IR $\left(\mathrm{KBr}, \mathrm{cm}^{-1}\right): 2926,2856,1643,1547,1369,1133,856,725,587$; HRMS (ESI) $m / z$ : $[\mathrm{M}+\mathrm{H}]^{+}$calcd for $\mathrm{C}_{14} \mathrm{H}_{17} \mathrm{~N}_{2} \mathrm{O} 229.1341$, found 229.1340.

$N$-Benzylbenzamide (2s). White solid (192 mg, 91\%); $R_{\mathrm{f}}=$ 0.50 (EtOAc/hexane) 2:8; mp 80-82 ${ }^{\circ} \mathrm{C} ;{ }^{1} \mathrm{H}$ NMR (600 MHz, $\left.\mathrm{CDCl}_{3}\right) \delta 7.79-7.78(\mathrm{~d}, J=7.2 \mathrm{~Hz}, 2 \mathrm{H}), 7.51-7.48(\mathrm{t}, J=7.2 \mathrm{~Hz}$, $1 \mathrm{H}), 7.43-7.41(\mathrm{t}, J=7.2 \mathrm{~Hz}, 2 \mathrm{H}), 7.35-7.34(\mathrm{~d}, J=4.2 \mathrm{~Hz}$, $4 \mathrm{H}), 7.32-7.28(\mathrm{~m}, 1 \mathrm{H}), 6.59(\mathrm{br}, 1 \mathrm{H}), 4.64-4.63(\mathrm{~d}, J=6.0 \mathrm{~Hz}$, $2 \mathrm{H}) ;{ }^{13} \mathrm{C}$ NMR $\left(150 \mathrm{MHz}, \mathrm{CDCl}_{3}\right) \delta 167.9,138.3,134.3,131.7$, 128.8, 128.7, 128.0, 127.7, 127.2, 44.2; FT-IR $\left(\mathrm{KBr}, \mathrm{cm}^{-1}\right): 2954$, $1637,1552,1416,1316,1260,985,805,725,695,461$; HRMS (ESI) $m / z:[\mathrm{M}+\mathrm{H}]^{+}$calcd for $\mathrm{C}_{14} \mathrm{H}_{14} \mathrm{NO} 212.1075$, found 212.1075 .

$\mathrm{N}$-Cyclohexylbenzamide (2t). Light yellow solid (189 mg, 93\%); $R_{\mathrm{f}}=0.50$ (EtOAc/hexane) $2: 8 ; \mathrm{mp} 152-154{ }^{\circ} \mathrm{C} ;{ }^{1} \mathrm{H}$ NMR $\left(600 \mathrm{MHz}, \mathrm{CDCl}_{3}\right) \delta 7.75-7.74(\mathrm{~d}, J=7.2 \mathrm{~Hz}, 2 \mathrm{H}), 7.49-$ $7.46(\mathrm{t}, J=7.2 \mathrm{~Hz}, 1 \mathrm{H}), 7.43-7.40(\mathrm{t}, J=7.8 \mathrm{~Hz}, 2 \mathrm{H}), 6.02(\mathrm{br} \mathrm{s}$, $1 \mathrm{H}), 4.00-3.94(\mathrm{~m}, 1 \mathrm{H}), 2.04-2.01(\mathrm{~m}, 2 \mathrm{H}), 1.76-1.73(\mathrm{~m}$, $3 \mathrm{H}), 1.66-1.64(\mathrm{~m}, 1 \mathrm{H}), 1.45-1.38(\mathrm{~m}, 2 \mathrm{H}), 1.26-1.18(\mathrm{~m}$, $2 \mathrm{H}) ;{ }^{13} \mathrm{C}$ NMR $\left(150 \mathrm{MHz}, \mathrm{CDCl}_{3}\right) \delta 167.5,134.8,131.4,128.5$, 126.9, 48.9, 33.0, 32.9, 25.5, 25.0; FT-IR (KBr, cm $\left.{ }^{-1}\right): 2927$, $2850,1624,1574,1452,1261,1082,700$; HRMS (ESI) $m / z$ : [M $+\mathrm{H}]^{+}$calcd for $\mathrm{C}_{13} \mathrm{H}_{18} \mathrm{NO} 204.1388$, found 204.1395.

$\mathrm{N}$-Benzyl-2-naphthamide (2u). Brown solid $(232 \mathrm{mg}$, $89 \%) ; R_{\mathrm{f}}=0.50$ (EtOAc/hexane) $2: 8 ; \mathrm{mp} 138-140{ }^{\circ} \mathrm{C} ;{ }^{1} \mathrm{H}$ NMR (400 MHz, $\left.\mathrm{CDCl}_{3}\right) \delta 8.32(\mathrm{~s}, 1 \mathrm{H}), 7.88-7.85(\mathrm{~m}, 4 \mathrm{H})$, 7.59-7.50 (m, 2H), 7.40-7.29 (m, 5H), 6.86 (br s, 1H), 4.70$4.68(\mathrm{~d}, J=5.6 \mathrm{~Hz}, 2 \mathrm{H}) ;{ }^{13} \mathrm{C} \mathrm{NMR}\left(150 \mathrm{MHz}, \mathrm{CDCl}_{3}\right) \delta 167.7$, $138.4,134.8,132.7,131.7,129.1,128.9,128.5,128.0,127.8$, 127.7, 127.6, 127.5, 126.8, 123.8, 44.3; FT-IR $\left(\mathrm{KBr}, \mathrm{cm}^{-1}\right): 2923$, $2853,1637,1547,1414,1320,1264,1146,1048,835,780,694$, 478; HRMS (ESI) $m / z:[\mathrm{M}+\mathrm{H}]^{+}$calcd for $\mathrm{C}_{18} \mathrm{H}_{16} \mathrm{NO} 262.1232$, found 262.1235 .

$\mathrm{N}$-(tert-Butyl)picolinamide (2v). Brown liquid (153 mg, $86 \%) ; R_{\mathrm{f}}=0.50$ (EtOAc/hexane) $2: 8 ;{ }^{1} \mathrm{H}$ NMR (400 MHz, $\left.\mathrm{CDCl}_{3}\right) \delta 8.51-8.50(\mathrm{~d}, J=4.8 \mathrm{~Hz}, 1 \mathrm{H}), 8.18-8.16(\mathrm{~d}, J=11.0$ $\mathrm{Hz}, 1 \mathrm{H}), 8.01($ br s, $1 \mathrm{H}), 7.84-7.80(\mathrm{t}, J=7.6 \mathrm{~Hz}, 1 \mathrm{H}), 7.41-$ $7.37(\mathrm{~m}, 1 \mathrm{H}), 1.49(\mathrm{~s}, 9 \mathrm{H}) ;{ }^{13} \mathrm{C} \mathrm{NMR}\left(100 \mathrm{MHz}, \mathrm{CDCl}_{3}\right) \delta$ 163.6, 151.0, 147.9, 137.9, 126.0, 121.9, 51.0, 28.9; FT-IR (KBr, $\left.\mathrm{cm}^{-1}\right): 2966,1679,1522,1461,1365,1231,998,751,621$; HRMS (ESI) $m / z:[\mathrm{M}+\mathrm{H}]^{+}$calcd for $\mathrm{C}_{10} \mathrm{H}_{15} \mathrm{~N}_{2} \mathrm{O}$ 179.1184, found 179.1188 .

$\mathrm{N}$-(tert-Butyl)-2-naphthamide (2w). White solid (182 mg, $80 \%$ ); $R_{\mathrm{f}}=0.50$ (EtOAc/hexane) $2: 8 ; \mathrm{mp} 162-164{ }^{\circ} \mathrm{C} ;{ }^{1} \mathrm{H}$ NMR $\left(600 \mathrm{MHz}, \mathrm{CDCl}_{3}\right) \delta 8.21(\mathrm{~s}, 1 \mathrm{H}), 7.90-7.89(\mathrm{~d}, J=7.8$ $\mathrm{Hz}, 1 \mathrm{H}), 7.86-7.84(\mathrm{t}, J=6.6 \mathrm{~Hz}, 2 \mathrm{H}), 7.79-7.77(\mathrm{~m}, 1 \mathrm{H})$, 7.55-7.51 (m, 2H), 6.23 (br s, $1 \mathrm{H}), 1.52(\mathrm{~s}, 9 \mathrm{H}) ;{ }^{13} \mathrm{C}$ NMR $(150$ $\left.\mathrm{MHz} \mathrm{CDCl}_{3}\right) \delta 167.2,134.7,133.3,132.8,129.0,128.5,127.8$, 127.6, 127.1, 126.8, 123.8, 51.9, 29.1; FT-IR $\left(\mathrm{KBr}, \mathrm{cm}^{-1}\right): 2963$, 1638, 1571, 1452, 1318, 834, 474; HRMS (ESI) $m / z:[\mathrm{M}+\mathrm{H}]^{+}$ calcd for $\mathrm{C}_{15} \mathrm{H}_{18} \mathrm{NO} 228.1388$, found 228.1384 .

(S)-Methyl-2-(4-bromobenzamido)propanoate (2x). White solid (239 mg, 84\%); $R_{\mathrm{f}}=0.50$ (EtOAc/hexane) 2:8; $\mathrm{mp} 104-106{ }^{\circ} \mathrm{C} ;{ }^{1} \mathrm{H} \mathrm{NMR}\left(600 \mathrm{MHz}, \mathrm{CDCl}_{3}\right) \delta 7.64-7.62(\mathrm{~d}, J$ $=8.4 \mathrm{~Hz}, 2 \mathrm{H}), 7.51-7.50(\mathrm{~d}, J=8.4 \mathrm{~Hz}, 2 \mathrm{H}), 6.99(\mathrm{br} \mathrm{s}, 1 \mathrm{H})$, 4.76-4.72 (m, 1H), $3.75(\mathrm{~s}, 3 \mathrm{H}), 1.48-1.47(\mathrm{~d}, J=7.2 \mathrm{~Hz}, 3 \mathrm{H})$; ${ }^{13} \mathrm{C} \mathrm{NMR}\left(150 \mathrm{MHz}, \mathrm{CDCl}_{3}\right) \delta 173.8,166.1,132.8,131.9,128.9$, 126.6, 52.8, 48.7, 18.6; FT-IR (KBr, $\left.\mathrm{cm}^{-1}\right)$ : 2958, 2853, 1918, $1748,1637,1531,1462,1365,1224,1170,845,762,620,552$;
LRMS (ESI) $m / z:[\mathrm{M}+\mathrm{H}]^{+}$calcd for $\mathrm{C}_{11} \mathrm{H}_{13} \mathrm{BrNO}_{3}$ 286.0079, found 286.9795 .

(S)-Methyl-3-phenyl-2-pivalamidopropanoate (2y). White solid (213 mg, 81\%); $R_{\mathrm{f}}=0.50$ (EtOAc/hexane) 2:8; $\mathrm{mp} 88-90{ }^{\circ} \mathrm{C}$; ${ }^{1} \mathrm{H}$ NMR $\left(600 \mathrm{MHz}, \mathrm{CDCl}_{3}\right) \delta 7.30-7.25(\mathrm{~m}$, $3 \mathrm{H}), 7.09-7.07$ (d, $J=7.2 \mathrm{~Hz}, 2 \mathrm{H}), 6.06($ br s, $1 \mathrm{H}), 4.88-4.85$ (m, 1H), $3.74(\mathrm{~s}, 3 \mathrm{H}), 3.19-3.08(\mathrm{~m}, 2 \mathrm{H}), 1.15(\mathrm{~s}, 9 \mathrm{H}) ;{ }^{13} \mathrm{C}$ NMR $\left(150 \mathrm{MHz}, \mathrm{CDCl}_{3}\right) \delta 178.0,172.4,136.0,129.4,128.6$, 127.2, 53.0, 52.4, 38.7, 37.8, 27.4; FT-IR $\left(\mathrm{KBr}, \mathrm{cm}^{-1}\right): 2973$, $1754,1731,1634,1531,1202,1038,754,702 ; \mathrm{HRMS}$ (ESI) $\mathrm{m} / z$ : $[\mathrm{M}+\mathrm{H}]^{+}$calcd for $\mathrm{C}_{15} \mathrm{H}_{22} \mathrm{NO}_{3} 264.1600$, found 264.1608 .

$\mathrm{N}$-Cyclohexyl-2-phenylacetamide (2z). Light yellow solid (197 mg, 91\%); $R_{\mathrm{f}}=0.50$ (EtOAc/hexane) $2: 8 ; \mathrm{mp} 131{ }^{\circ} \mathrm{C} ;{ }^{1} \mathrm{H}$ $\operatorname{NMR}\left(600 \mathrm{MHz}, \mathrm{CDCl}_{3}\right) \delta 7.37-7.34(\mathrm{t}, J=7.2 \mathrm{~Hz}, 2 \mathrm{H}), 7.31-$ $7.24(\mathrm{~m}, 3 \mathrm{H}), 5.24(\mathrm{br} \mathrm{s}, 1 \mathrm{H}), 3.78-3.72(\mathrm{~m}, 1 \mathrm{H}), 3.55(\mathrm{~s}, 2 \mathrm{H})$, $1.84-1.81(\mathrm{~m}, 2 \mathrm{H}), 1.62-1.55(\mathrm{~m}, 3 \mathrm{H}), 1.35-1.25(\mathrm{~m}, 2 \mathrm{H})$, $1.12-0.97(\mathrm{~m}, 3 \mathrm{H}) ;{ }^{13} \mathrm{C}$ NMR $\left(150 \mathrm{MHz}, \mathrm{CDCl}_{3}\right) \delta 170.2$, 135.3, 129.4, 128.9, 127.2, 48.3, 43.9, 32.9, 25.5, 24.8; FT-IR $\left(\mathrm{KBr}, \mathrm{cm}^{-1}\right): 2966,1679,1522,1461,1365,1231,998,751,621$; LRMS (ESI) $m / z$ : $[\mathrm{M}+\mathrm{H}]^{+}$calcd for $\mathrm{C}_{14} \mathrm{H}_{20} \mathrm{NO} 218.1545$, found 218.1625 .

(S)-Methyl-2-(2-benzamido-2-methylpropanamido)-3methylbutanoate (3a). White solid (256 mg, 80\%); $R_{\mathrm{f}}=0.50$ (EtOAc/hexane) 4:6; mp 109-111 ${ }^{\circ} \mathrm{C}$; ${ }^{1} \mathrm{H}$ NMR (600 MHz, $\left.\mathrm{CDCl}_{3}\right) \delta 7.78-7.77(\mathrm{~d}, J=7.8 \mathrm{~Hz}, 2 \mathrm{H}), 7.51-7.49(\mathrm{t}, J=7.2 \mathrm{~Hz}$, $1 \mathrm{H}), 7.44-7.42(\mathrm{t}, J=7.2 \mathrm{~Hz}, 2 \mathrm{H}), 7.01(\mathrm{br}, 1 \mathrm{H}), 6.91(\mathrm{br}, 1 \mathrm{H})$, $4.56-4.54(\mathrm{~m}, 1 \mathrm{H}), 3.73(\mathrm{~s}, 3 \mathrm{H}), 2.24-2.18(\mathrm{~m}, 1 \mathrm{H}), 1.73-1.71$ $(\mathrm{d}, J=8.4 \mathrm{~Hz}, 6 \mathrm{H}), 0.97-0.90(\mathrm{dd}, J=7.2 \mathrm{~Hz}, 6 \mathrm{H}) ;{ }^{13} \mathrm{C} \mathrm{NMR}$ $\left(150 \mathrm{MHz}, \mathrm{CDCl}_{3}\right) \delta 174.7,172.6,167.4,134.9,131.9,128.8$, 127.1, 57.9, 57.6, 52.4, 31.5, 25.7, 19.2; FT-IR $\left(\mathrm{KBr}, \mathrm{cm}^{-1}\right): 2960$, $1745,1655,1532,1314,1194,1021,694$; HRMS (ESI) $m / z:[M$ $+\mathrm{H}]^{+}$calcd for $\mathrm{C}_{17} \mathrm{H}_{25} \mathrm{~N}_{2} \mathrm{O}_{4} 321.1814$, found 321.1813 .

(S)-Methyl-2-((S)-2-((((9H-fluoren-9-yl)methoxy)carbonyl)amino)propanamido)-3-phenylpropanoate (3b). White solid (420 mg, 89\%); $R_{\mathrm{f}}=0.50$ (EtOAc/hexane) 4:6; $\mathrm{mp} 185-187^{\circ} \mathrm{C}$; ${ }^{1} \mathrm{H}$ NMR $\left(600 \mathrm{MHz}, \mathrm{CDCl}_{3}\right) \delta 7.77-7.76(\mathrm{~d}, J$ $=7.8 \mathrm{~Hz}, 2 \mathrm{H}), 7.55-7.52(\mathrm{t}, J=7.8 \mathrm{~Hz}, 2 \mathrm{H}), 7.41-7.39(\mathrm{t}, J=7.2$ $\mathrm{Hz}, 2 \mathrm{H}), 7.31-7.19(\mathrm{~m}, 8 \mathrm{H}), 6.38(\mathrm{br}, 1 \mathrm{H}), 5.42(\mathrm{br}, 1 \mathrm{H}), 4.51-$ $4.49(\mathrm{t}, J=7.2 \mathrm{~Hz}, 1 \mathrm{H}), 4.44-4.41(\mathrm{~m}, 2 \mathrm{H}), 4.33-4.30(\mathrm{t}, J=6.6$ $\mathrm{Hz}, 1 \mathrm{H}), 4.19-4.17(\mathrm{t}, J=7.2 \mathrm{~Hz}, 1 \mathrm{H}), 3.71(\mathrm{~s}, 3 \mathrm{H}), 3.12-3.03$ $(\mathrm{m}, 2 \mathrm{H}), 1.35-1.33(\mathrm{~d}, J=7.2 \mathrm{~Hz}, 3 \mathrm{H}) ;{ }^{13} \mathrm{C}$ NMR $(150 \mathrm{MHz}$, $\left.\mathrm{CDCl}_{3}\right) \delta 173.0,170.5,156.1,143.8,141.5,136.4,129.6,128.9$, 127.9, 127.3, 125.2, 120.2, 67.3, 56.2, 52.7, 48.4, 47.3, 38.8, 18.5; FT-IR $\left(\mathrm{KBr}, \mathrm{cm}^{-1}\right): 2923,2852,1737,1696,1649,1538,1105$, 619; HRMS (ESI) $m / z$ : $[\mathrm{M}+\mathrm{H}]^{+}$calcd for $\mathrm{C}_{28} \mathrm{H}_{29} \mathrm{~N}_{2} \mathrm{O}_{5}$ 473.2076, found 473.2076.

(R)-Methyl-2-((S)-2-((((9H-fluoren-9-yl)methoxy)carbonyl)amino)-4-methylpentanamido)-3-methylbutanoate (3c). White solid (396 mg, 85\%); $R_{\mathrm{f}}=0.50$ (EtOAc/ hexane) 4:6; mp $130-132{ }^{\circ} \mathrm{C} ;{ }^{1} \mathrm{H}$ NMR (600 MHz, $\left.\mathrm{CDCl}_{3}\right) \delta$ $7.77-7.75(\mathrm{~d}, J=7.8 \mathrm{~Hz}, 2 \mathrm{H}), 7.58-7.57(\mathrm{~d}, J=6.6 \mathrm{~Hz}, 2 \mathrm{H})$, $7.41-7.38(\mathrm{t}, J=7.2 \mathrm{~Hz}, 2 \mathrm{H}), 7.32-7.29(\mathrm{t}, J=6.6 \mathrm{~Hz}, 2 \mathrm{H}), 6.52$ $(\mathrm{br}, 1 \mathrm{H}), 5.30(\mathrm{br}, 1 \mathrm{H}), 4.54-4.52(\mathrm{~m}, 1 \mathrm{H}), 4.43-4.37(\mathrm{~m}, 2 \mathrm{H})$, $4.26-4.20(\mathrm{~m}, 2 \mathrm{H}), 3.73(\mathrm{~s}, 3 \mathrm{H}), 2.18-2.15(\mathrm{~m}, 1 \mathrm{H}), 1.69-1.63$ $(\mathrm{m}, 2 \mathrm{H}), 1.58-1.53(\mathrm{~m}, 1 \mathrm{H}), 0.96-0.94(\mathrm{~m}, 6 \mathrm{H}), 0.91-0.88(\mathrm{~m}$, $6 \mathrm{H}) ;{ }^{13} \mathrm{C} \mathrm{NMR}\left(150 \mathrm{MHz}, \mathrm{CDCl}_{3}\right) \delta 172.4,172.3,156.4,143.4$, $141.4,127.9,127.2$, 125.2, 120.1, 67.2, 57.3, 53.7, 52.3, 47.3, 41.5, 31.4, 24.8, 23.1, 22.2, 19.1, 17.9; FT-IR $\left(\mathrm{KBr}, \mathrm{cm}^{-1}\right): 3257,2962$, $1724,1649,1535,1252,743,619$; HRMS (ESI) $m / z:[\mathrm{M}+\mathrm{H}]^{+}$ calcd for $\mathrm{C}_{27} \mathrm{H}_{35} \mathrm{~N}_{2} \mathrm{O}_{5}$ 467.2546, found 467.2537.

(S)-Methyl-2-(2-((( $9 H$-fluoren-9-yl)methoxy)carbonyl)amino)-2-methylpropanamido)propanoate (3d). Yellowish liquid (365 mg, 89\%); $R_{\mathrm{f}}=0.50$ (EtOAc/hexane) 
4:6; ${ }^{1} \mathrm{H}$ NMR $\left(600 \mathrm{MHz}, \mathrm{CDCl}_{3}\right) \delta 7.79-7.76(\mathrm{~d}, J=7.8 \mathrm{~Hz}$, $2 \mathrm{H}), 7.62-7.61(\mathrm{~d}, J=6.6 \mathrm{~Hz}, 2 \mathrm{H}), 7.43-7.39(\mathrm{~m}, 2 \mathrm{H}), 7.35-$ $7.31(\mathrm{~m}, 2 \mathrm{H}), 7.09(\mathrm{br}, 1 \mathrm{H}), 6.04(\mathrm{br}, 1 \mathrm{H}), 4.43(\mathrm{~s}, 2 \mathrm{H}), 4.22-$ $4.21(\mathrm{~m}, 1 \mathrm{H}), 4.10-4.07(\mathrm{~m}, 1 \mathrm{H}), 3.73(\mathrm{~s}, 3 \mathrm{H}), 1.50-1.38(\mathrm{~m}$, $9 \mathrm{H}) ;{ }^{13} \mathrm{C}$ NMR $\left(150 \mathrm{MHz}, \mathrm{CDCl}_{3}\right) \delta 174.2,173.4,155.1,143.8$, 141.3, 127.7, 127.1, 125.0, 120.0, 66.6, 56.8, 52.4, 48.3, 47.2, 25.5, 18.1; FT-IR $\left(\mathrm{KBr}, \mathrm{cm}^{-1}\right):$ 2984, 1732, 1652, 1255, 739, 620; HRMS (ESI) $m / z$ : $[\mathrm{M}+\mathrm{H}]^{+}$calcd for $\mathrm{C}_{23} \mathrm{H}_{27} \mathrm{~N}_{2} \mathrm{O}_{5} 411.1920$, found 411.1929 .

(S)-Methyl-2-((S)-2-((((9H-fluoren-9-yl)methoxy)carbonyl)amino)-3-phenylpropanamido)-2-phenylacetate (3e). White solid (459 mg, 86\%); $R_{\mathrm{f}}=0.50$ (EtOAc/ hexane) 4:6; mp $176-178{ }^{\circ} \mathrm{C} ;{ }^{1} \mathrm{H}$ NMR $\left(600 \mathrm{MHz}, \mathrm{CDCl}_{3}\right) \delta$ $7.76-7.75(\mathrm{~d}, J=7.2 \mathrm{~Hz}, 2 \mathrm{H}), 7.54-7.51(\mathrm{t}, J=7.2 \mathrm{~Hz}, 2 \mathrm{H})$, $7.41-7.38(\mathrm{t}, J=7.2 \mathrm{~Hz}, 2 \mathrm{H}), 7.30-7.25(\mathrm{~m}, 10 \mathrm{H}), 7.18-7.17$ $(\mathrm{m}, 2 \mathrm{H}), 6.78(\mathrm{br}, 1 \mathrm{H}), 5.46-5.45(\mathrm{~d}, J=6.6 \mathrm{~Hz}, 1 \mathrm{H}), 5.37(\mathrm{br}$, $1 \mathrm{H}), 4.52(\mathrm{br}, 1 \mathrm{H}), 4.42-4.37(\mathrm{~m}, 1 \mathrm{H}), 4.32-4.31(\mathrm{~d}, J=6.6 \mathrm{~Hz}$, $1 \mathrm{H}), 4.18-4.16(\mathrm{t}, J=7.2 \mathrm{~Hz}, 1 \mathrm{H}), 3.68(\mathrm{~s}, 3 \mathrm{H}), 3.18-3.01(\mathrm{~m}$, $2 \mathrm{H}) ;{ }^{13} \mathrm{C} \mathrm{NMR}\left(150 \mathrm{MHz}, \mathrm{CDCl}_{3}\right) \delta 170.8,170.4,156.1,144.0$, $141.5,136.1,129.1,128.9,128.8,127.9,127.4,127.3,125.2$, 120.2, 67.3, 56.8, 56.1, 53.0, 47.3, 38.8; FT-IR $\left(\mathrm{KBr}, \mathrm{cm}^{-1}\right): 2921$, 1739, 1690, 1654, 1535, 1283, 730; LRMS (ESI) $m / z:[\mathrm{M}+\mathrm{H}]^{+}$ calcd for $\mathrm{C}_{33} \mathrm{H}_{31} \mathrm{~N}_{2} \mathrm{O}_{5}$ 535.2233, found 535.2211.

(S)-Methyl-2-((S)-2-((((9H-fluoren-9-yl)methoxy)carbonyl)amino)-3-methylbutanamido)-2-phenylacetate (3f). White solid (423 mg, 87\%); $R_{\mathrm{f}}=0.50$ (EtOAc/hexane) 4:6; mp 190-192 ${ }^{\circ} \mathrm{C}$; ${ }^{1} \mathrm{H} \mathrm{NMR}\left(600 \mathrm{MHz}, \mathrm{CDCl}_{3}\right) \delta 7.76-7.75$ $(\mathrm{d}, J=7.2 \mathrm{~Hz}, 2 \mathrm{H}), 7.57-7.56(\mathrm{t}, J=7.2 \mathrm{~Hz}, 2 \mathrm{H}), 7.41-7.38(\mathrm{~m}$, $2 \mathrm{H}), 7.33-7.29(\mathrm{~m}, 7 \mathrm{H}), 6.79(\mathrm{br}, 1 \mathrm{H}), 5.54-5.52(\mathrm{~d}, J=7.2 \mathrm{~Hz}$, $1 \mathrm{H}), 5.40(\mathrm{br}, 1 \mathrm{H}), 4.41-4.38(\mathrm{t}, J=7.8 \mathrm{~Hz}, 1 \mathrm{H}), 4.35-4.32(\mathrm{t}, J$ $=6.6 \mathrm{~Hz}, 1 \mathrm{H}), 4.21-4.18(\mathrm{t}, J=7.2 \mathrm{~Hz}, 1 \mathrm{H}), 4.07-4.06(\mathrm{t}, J=7.2$ $\mathrm{Hz}, 1 \mathrm{H}), 3.73(\mathrm{~s}, 3 \mathrm{H}), 2.17-2.13(\mathrm{~m}, 1 \mathrm{H}), 1.01-0.96$ (dd, $J=6.6$ $\mathrm{Hz}, 6 \mathrm{H}) ;{ }^{13} \mathrm{C} \mathrm{NMR}\left(150 \mathrm{MHz}, \mathrm{CDCl}_{3}\right) \delta 171.2,170.9,156.6$, $144.1,141.5,136.0,129.3,128.9,127.9,127.5,127.3,125.3$, 120.2, 67.3, 60.4, 56.8, 53.1, 47.3, 31.6, 18.1; FT-IR $\left(\mathrm{KBr}, \mathrm{cm}^{-1}\right)$ : 3064, 2957, 1738, 1691, 1653, 1536, 1450, 1389, 1289, 1174, 1034, 732, 647; LRMS (ESI) $m / z:[\mathrm{M}+\mathrm{H}]^{+}$calcd for $\mathrm{C}_{29} \mathrm{H}_{31} \mathrm{~N}_{2} \mathrm{O}_{5}$ 487.2233, found 487.2135.

(S)-Methyl-2-((S)-2-((((9H-fluoren-9-yl)methoxy)carbonyl)amino)propanamido)-4-methylpentanoate (3g). White solid (390 mg, 89\%); $R_{\mathrm{f}}=0.50$ (EtOAc/hexane) 4:6; $\mathrm{mp} 126-128^{\circ} \mathrm{C} ;{ }^{1} \mathrm{H} \mathrm{NMR}\left(600 \mathrm{MHz}, \mathrm{CDCl}_{3}\right) \delta 7.77-7.75$ (d, $=7.8 \mathrm{~Hz}, 2 \mathrm{H}), 7.59-7.58(\mathrm{t}, J=7.2 \mathrm{~Hz}, 2 \mathrm{H}), 7.41-7.39(\mathrm{t}, J=7.2$ $\mathrm{Hz}, 2 \mathrm{H}), 7.32-7.30$ (t, $J=7.2 \mathrm{~Hz}, 2 \mathrm{H}), 6.41(\mathrm{br}, 1 \mathrm{H}), 5.45$ (br, $1 \mathrm{H}), 4.64-4.59(\mathrm{~m}, 1 \mathrm{H}), 4.39-4.38(\mathrm{~d}, J=6.6 \mathrm{~Hz}, 2 \mathrm{H}), 4.32-$ $4.26(\mathrm{~m}, 1 \mathrm{H}), 4.22-4.20(\mathrm{t}, J=7.2 \mathrm{~Hz}, 1 \mathrm{H}), 3.73(\mathrm{~s}, 3 \mathrm{H}), 1.67-$ $1.61(\mathrm{~m}, 2 \mathrm{H}), 1.56-1.53(\mathrm{~m}, 1 \mathrm{H}), 1.41-1.40(\mathrm{~d}, J=7.2 \mathrm{~Hz}, 3 \mathrm{H})$, $0.91-0.89(\mathrm{t}, J=7.2 \mathrm{~Hz}, 6 \mathrm{H}) ;{ }^{13} \mathrm{C} \mathrm{NMR}\left(150 \mathrm{MHz}, \mathrm{CDCl}_{3}\right) \delta$ $173.4,172.3,157.0,144.0,141.5,127.9,127.2,125.2,120.2,67.1$, 54.6, 52.2, 47.3, 41.4, 24.8, 23.0, 17.6; FT-IR $\left(\mathrm{KBr}, \mathrm{cm}^{-1}\right): 2955$, 1744, 1691, 1653, 1537, 1448, 1258, 738; HRMS (ESI) $m / z$ : [M $+\mathrm{H}]^{+}$calcd for $\mathrm{C}_{25} \mathrm{H}_{31} \mathrm{~N}_{2} \mathrm{O}_{5} 439.2233$, found 439.2226 .

DL-(S)-Methyl-2-((S)-2-((( $9 H$-fluoren-9-yl)methoxy)carbonyl)amino)propanamido)-4-methylpentanoate (3h). White solid (372 mg, 85\%); $R_{\mathrm{f}}=0.50$ (EtOAc/hexane) 4:6; $\mathrm{mp} 126-128^{\circ} \mathrm{C} ;{ }^{1} \mathrm{H} \mathrm{NMR}\left(600 \mathrm{MHz}, \mathrm{CDCl}_{3}\right) \delta 7.76-7.74$ (d, $J$ $=7.2 \mathrm{~Hz}, 2 \mathrm{H}), 7.59-7.58(\mathrm{~d}, J=7.8 \mathrm{~Hz}, 2 \mathrm{H}), 7.40-7.37(\mathrm{t}, J=$ $7.2 \mathrm{~Hz}, 2 \mathrm{H}), 7.31-7.28(\mathrm{t}, J=7.2 \mathrm{~Hz}, 2 \mathrm{H}), 6.91(\mathrm{br}, 1 \mathrm{H}), 6.77$ (br, $1 \mathrm{H}), 5.75-5.72(\mathrm{t}, J=7.8 \mathrm{~Hz}, 1 \mathrm{H}), 4.64-4.60(\mathrm{~m}, 1 \mathrm{H})$, 4.40-4.34 (m, 3H), 4.24-4.20 (m, 1H), 3.71, $3.68(\mathrm{~s}, 3 \mathrm{H})$, $1.67-1.62(\mathrm{~m}, 2 \mathrm{H}), 1.58-1.53(\mathrm{~m}, 1 \mathrm{H}), 1.42-1.40(\mathrm{~d}, J=7.2$ $\mathrm{Hz}, 3 \mathrm{H}), 0.91-0.88(\mathrm{~m}, 6 \mathrm{H}) ;{ }^{13} \mathrm{C} \mathrm{NMR}\left(150 \mathrm{MHz}, \mathrm{CDCl}_{3}\right) \delta$ $173.4,173.3,172.5,172.4,156.8,156.2,143.8,141.4,127.9$,
127.2, 125.2, 120.1, 67.3, 52.5, 52.4, 50.9, 47.2, 41.4, 25.0, 22.9, 22.0, 21.9, 19.1; FT-IR (KBr, cm $\left.{ }^{-1}\right): 2955,1744,1691,1653$, 1537, 1448, 1258, 738; HRMS (ESI) $m / z:[\mathrm{M}+\mathrm{H}]^{+}$calcd for $\mathrm{C}_{25} \mathrm{H}_{31} \mathrm{~N}_{2} \mathrm{O}_{5}$ 439.2233, found 439.2200.

(S)-Methyl-2-(2-(( ( $9 H$-fluoren-9-yl)methoxy)carbonyl)amino)acetamido)-3-phenylpropanoate (3i). White solid (403 mg, 88\%); $R_{\mathrm{f}}=0.50$ (EtOAc/hexane) 4:6; mp 175-178 ${ }^{\circ} \mathrm{C} ;{ }^{1} \mathrm{H}$ NMR (400 MHz, $\mathrm{CDCl}_{3}$ ) $\delta 7.77-7.75$ (d, $=7.6 \mathrm{~Hz}, 2 \mathrm{H}), 7.59-7.57(\mathrm{~d}, J=7.2 \mathrm{~Hz}, 2 \mathrm{H}), 7.42-7.38(\mathrm{t}, J=$ $7.2 \mathrm{~Hz}, 2 \mathrm{H}), 7.32-7.28(\mathrm{t}, J=7.6 \mathrm{~Hz}, 2 \mathrm{H}), 7.23-7.19(\mathrm{~m}, 3 \mathrm{H})$, $7.08-7.06(\mathrm{~d}, J=7.2 \mathrm{~Hz}, 2 \mathrm{H}), 6.59(\mathrm{br}, 1 \mathrm{H}), 5.57(\mathrm{br}, 1 \mathrm{H})$, $4.91-4.86(\mathrm{~m}, 1 \mathrm{H}), 4.39-4.37(\mathrm{~d}, J=7.2 \mathrm{~Hz}, 2 \mathrm{H}), 4.22-4.19(\mathrm{t}$, $J=7.2 \mathrm{~Hz}, 1 \mathrm{H}), 3.88-3.85(\mathrm{t}, J=8.0 \mathrm{~Hz}, 1 \mathrm{H}), 3.71(\mathrm{~s}, 3 \mathrm{H})$, 3.16-3.06 (m, 2H); $\left.{ }^{13} \mathrm{C} \mathrm{NMR} \mathrm{(100} \mathrm{MHz,} \mathrm{CDCl}_{3}\right) \delta 171.9$, $168.7,156.5,143.9,141.5,135.7,128.8,127.9,127.4,127.3$, 125.2, 120.2, 67.2, 60.2, 53.3, 47.1, 44.4, 37.8; FT-IR (KBr, $\left.\mathrm{cm}^{-1}\right): 2951,1734,1668,1525,1449,1216,1047,741$; HRMS (ESI) $m / z:[\mathrm{M}+\mathrm{H}]^{+}$calcd for $\mathrm{C}_{27} \mathrm{H}_{27} \mathrm{~N}_{2} \mathrm{O}_{5}$ 459.1920, found 459.1921.

Methyl-2-(2-((((9H-fluoren-9-yl)methoxy)carbonyl)amino)-2-methylpropanamido)acetate (3j). Yellowish solid (337 mg, 85\%); $R_{\mathrm{f}}=0.50$ (EtOAc/hexane) $4: 6 ;{ }^{1} \mathrm{H}$ NMR $\left(600 \mathrm{MHz}, \mathrm{CDCl}_{3}\right) \delta 7.77-7.76(\mathrm{~d}, J=7.2 \mathrm{~Hz}, 2 \mathrm{H}), 7.59-7.58$ $(\mathrm{d}, J=7.2 \mathrm{~Hz}, 2 \mathrm{H}), 7.41-7.39(\mathrm{t}, J=7.2 \mathrm{~Hz}, 2 \mathrm{H}), 7.33-7.30(\mathrm{t}, J$ $=7.2 \mathrm{~Hz}, 2 \mathrm{H}), 6.73(\mathrm{br}, 1 \mathrm{H}), 5.30(\mathrm{br}, 1 \mathrm{H}), 4.45(\mathrm{~s}, 2 \mathrm{H}), 4.21-$ $4.19(\mathrm{t}, J=6.6 \mathrm{~Hz}, 1 \mathrm{H}), 4.02(\mathrm{~s}, 2 \mathrm{H}), 3.74(\mathrm{~s}, 3 \mathrm{H}), 1.53(\mathrm{~s}, 6 \mathrm{H})$; ${ }^{13} \mathrm{C} \mathrm{NMR}\left(150 \mathrm{MHz} \mathrm{CDCl}_{3}\right) \delta 175.0,170.4,155.1,143.8,141.3$, 127.7, 127.0, 125.0, 120.0, 66.5, 60.4, 52.2, 47.2, 41.4, 25.3; FT-IR $\left(\mathrm{KBr}, \mathrm{cm}^{-1}\right): 2925,2854,1717,1664,1524,1450,1260,1090$, 739; HRMS (ESI) $m / z$ : $[\mathrm{M}+\mathrm{H}]^{+}$calcd for $\mathrm{C}_{22} \mathrm{H}_{25} \mathrm{~N}_{2} \mathrm{O}_{5}$ 397.1763, found 397.1765.

Methyl-2-((S)-2-(( ( $9 H$-fluoren-9-yl)methoxy)carbonyl)amino)-3-phenylpropanamido)-3-hydroxypropanoate (3k). White solid (444 mg, 91\%); $R_{\mathrm{f}}=0.50$ (EtOAc/ hexane) 4:6; mp 191-193 ${ }^{\circ} \mathrm{C}$; ${ }^{1} \mathrm{H}$ NMR (600 MHz, $\left.\mathrm{CDCl}_{3}\right) \delta$ $7.76-7.75(\mathrm{~d}, J=7.2 \mathrm{~Hz}, 2 \mathrm{H}), 7.53-7.51(\mathrm{t}, J=7.2 \mathrm{~Hz}, 2 \mathrm{H})$, $7.41-7.38(\mathrm{t}, J=7.2 \mathrm{~Hz}, 2 \mathrm{H}), 7.31-7.28(\mathrm{t}, J=7.2 \mathrm{~Hz}, 5 \mathrm{H})$, $7.19-7.18(\mathrm{~d}, J=6.6 \mathrm{~Hz}, 2 \mathrm{H}), 6.84(\mathrm{br}, 1 \mathrm{H}), 5.45(\mathrm{br}, 1 \mathrm{H}), 4.58$ $(\mathrm{s}, 1 \mathrm{H}), 4.46-4.38(\mathrm{~m}, 2 \mathrm{H}), 4.33-4.30(\mathrm{t}, J=7.2 \mathrm{~Hz}, 1 \mathrm{H}), 4.18-$ $4.15(\mathrm{t}, J=7.2 \mathrm{~Hz}, 1 \mathrm{H}), 3.90(\mathrm{~s}, 2 \mathrm{H}), 3.73(\mathrm{~s}, 3 \mathrm{H}), 3.10-3.09$ (d, $J=6.0 \mathrm{~Hz}, 2 \mathrm{H}) ;{ }^{13} \mathrm{C} \mathrm{NMR}\left(150 \mathrm{MHz}, \mathrm{CDCl}_{3}\right) \delta 171.5,170.6$, $156.4,143.8,141.5,136.3,129.5,128.9,128.0,127.3,127.2$, 125.3, 125.2, 120.2, 67.5, 63.0, 56.4, 55.1, 53.0, 47.2, 38.6; FT-IR $\left(\mathrm{KBr}, \mathrm{cm}^{-1}\right): 2925,1733,1662,1542,1450,1292,738,699$; LRMS (ESI) $m / z$ : $[\mathrm{M}+\mathrm{H}]^{+}$calcd for $\mathrm{C}_{28} \mathrm{H}_{29} \mathrm{~N}_{2} \mathrm{O}_{6} 489.2026$, found 489.2002

(S)-Methyl-2-((S)-2-((((9H-fluoren-9-yl)methoxy)carbonyl)amino)-3-phenylpropanamido)-3-phenylpropanoate (3I). White solid (488 mg, 89\%); $R_{\mathrm{f}}=0.50$ (EtOAc/ hexane) 4:6; mp 171-173 ${ }^{\circ} \mathrm{C} ;{ }^{1} \mathrm{H}$ NMR $\left(600 \mathrm{MHz}, \mathrm{CDCl}_{3}\right) \delta$ $7.77-7.76(\mathrm{~d}, J=7.2 \mathrm{~Hz}, 2 \mathrm{H}), 7.54-7.51(\mathrm{t}, J=7.8 \mathrm{~Hz}, 2 \mathrm{H})$, $7.42-7.39(\mathrm{t}, J=7.8 \mathrm{~Hz}, 2 \mathrm{H}), 7.32-7.24(\mathrm{~m}, 6 \mathrm{H}), 7.19-7.18(\mathrm{~d}$, $J=7.2 \mathrm{~Hz}, 2 \mathrm{H}), 6.25(\mathrm{br}, 1 \mathrm{H}), 5.31(\mathrm{br}, 1 \mathrm{H}), 4.79-4.76(\mathrm{~m}, 1 \mathrm{H})$, $4.43-4.41(\mathrm{~m}, 2 \mathrm{H}), 4.29(\mathrm{br}, 1 \mathrm{H}), 4.19-4.17(\mathrm{t}, J=6.6 \mathrm{~Hz}, 1 \mathrm{H})$, $3.67(\mathrm{~s}, 3 \mathrm{H}), 3.09-3.00(\mathrm{~m}, 4 \mathrm{H}) ;{ }^{13} \mathrm{C} \mathrm{NMR}\left(150 \mathrm{MHz}, \mathrm{CDCl}_{3}\right)$ $\delta 171.5,170.5,155.8,143.9,141.5,135.7,129.6,129.4,128.9$, 128.7, 128.0, 127.3, 127.2, 125.2, 120.2, 67.3, 56.1, 53.5, 52.5, 47.3, 38.5, 38.1; FT-IR $\left(\mathrm{KBr}, \mathrm{cm}^{-1}\right): 2924,1738,1697,1644$, 1535, 1444, 1257, 1033, 738, 698; LRMS (ESI) $m / z:[\mathrm{M}+\mathrm{H}]^{+}$ calcd for $\mathrm{C}_{34} \mathrm{H}_{33} \mathrm{~N}_{2} \mathrm{O}_{5} 549.2389$, found 549.2388.

(S)-Methyl-2-((S)-2-((( $9 H$-fluoren-9-yl)methoxy)carbonyl)amino)propanamido)propanoate $(3 \mathrm{~m})$. White solid (360 mg, 91\%); $R_{\mathrm{f}}=0.50$ (EtOAc/hexane) 4:6; mp 
141-143 ${ }^{\circ} \mathrm{C} ;{ }^{1} \mathrm{H}$ NMR $\left(600 \mathrm{MHz}, \mathrm{CDCl}_{3}\right) \delta 7.77-7.76(\mathrm{~d}, J=$ $7.2 \mathrm{~Hz}, 2 \mathrm{H}), 7.60-7.58(\mathrm{~d}, J=7.2 \mathrm{~Hz}, 2 \mathrm{H}), 7.42-7.39(\mathrm{t}, J=7.2$ $\mathrm{Hz}, 2 \mathrm{H}), 7.33-7.31(\mathrm{t}, J=7.2 \mathrm{~Hz}, 2 \mathrm{H}), 6.43(\mathrm{br}, 1 \mathrm{H}), 5.35$ (br, $1 \mathrm{H}), 4.59-4.56(\mathrm{t}, J=7.2 \mathrm{~Hz}, 1 \mathrm{H}), 4.41(\mathrm{br}, 2 \mathrm{H}), 4.23-4.21(\mathrm{t}, J$ $=7.2 \mathrm{~Hz}, 2 \mathrm{H}), 3.76(\mathrm{~s}, 3 \mathrm{H}), 1.42-1.41(\mathrm{~d}, J=6.6 \mathrm{~Hz}, 6 \mathrm{H}) ;{ }^{13} \mathrm{C}$ NMR $\left(150 \mathrm{MHz}, \mathrm{CDCl}_{3}\right) \delta 173.3,172.0,156.1,144.0,141.5$, 127.9, 127.3, 125.2, 120.2, 67.3, 52.7, 50.6, 48.3, 47.3, 19.0, 18.5; FT-IR $\left(\mathrm{KBr}, \mathrm{cm}^{-1}\right): 2927,1741,1688,1650,1530,1451,1259$, 1050, 758; HRMS (ESI) $m / z$ : $[\mathrm{M}+\mathrm{H}]^{+}$calcd for $\mathrm{C}_{22} \mathrm{H}_{25} \mathrm{~N}_{2} \mathrm{O}_{5}$ 397.1763, found 397.1754.

Methyl-2-(2-((( $(9 H$-fluoren-9-yl)methoxy)carbonyl)amino)-3-phenylpropanamido)acetate (3n). White solid (408 mg, 89\%); $R_{\mathrm{f}}=0.40$ (EtOAc/hexane) 4:6; mp 143-146 ${ }^{\circ} \mathrm{C}$; ${ }^{1} \mathrm{H} \mathrm{NMR}\left(600 \mathrm{MHz}, \mathrm{CDCl}_{3}\right) \delta 7.76-7.75(\mathrm{~d}, J=7.2 \mathrm{~Hz}, 2 \mathrm{H})$, 7.54-7.51 (m, 2H), 7.41-7.38 (t, J=7.2 Hz, 2H), 7.31-7.28 (m, $4 \mathrm{H}), 7.25-7.20(\mathrm{~m}, 3 \mathrm{H}), 6.41(\mathrm{br}, 1 \mathrm{H}), 5.41(\mathrm{br}, 1 \mathrm{H}), 4.48-4.33$ $(\mathrm{m}, 3 \mathrm{H}), 4.19-4.17(\mathrm{t}, J=7.2 \mathrm{~Hz}, 1 \mathrm{H}), 4.05-3.91(\mathrm{~m}, 2 \mathrm{H}), 3.72$ (s, 3H), $3.10(\mathrm{~s}, 2 \mathrm{H}) ;{ }^{13} \mathrm{C} \mathrm{NMR}\left(150 \mathrm{MHz}, \mathrm{CDCl}_{3}\right) \delta 171.3$, $170.0,156.2$, 143.9, 141.5, 136.5, 129.5, 128.9, 127.9, 127.3, 127.2, 125.2, 120.2, 67.3, 56.2, 52.6, 47.3, 41.4, 38.6; FT-IR (KBr, $\left.\mathrm{cm}^{-1}\right): 3299,2921,1749,1692,1649,1540,1439,1260,1032$, 739; LRMS (ESI) $m / z$ : $[\mathrm{M}+\mathrm{H}]^{+}$calcd for $\mathrm{C}_{27} \mathrm{H}_{27} \mathrm{~N}_{2} \mathrm{O}_{5}$ 459.1920, found 459.1876 .

DL-Methyl-2-(2-((( $(9 H$-fluoren-9-yl)methoxy)carbonyl)amino)-3-phenylpropanamido)acetate (rac-3n). White solid (398 $\mathrm{mg}, 87 \%) ; R_{\mathrm{f}}=0.40$ (EtOAc/hexane) 4:6; mp 143-146 ${ }^{\circ} \mathrm{C}$; ${ }^{1} \mathrm{H}$ NMR $\left(600 \mathrm{MHz}, \mathrm{CDCl}_{3}\right) \delta 7.76-7.75(\mathrm{~d}, J=$ $7.2 \mathrm{~Hz}, 2 \mathrm{H}), 7.54-7.51(\mathrm{~m}, 2 \mathrm{H}), 7.41-7.38(\mathrm{t}, J=7.2 \mathrm{~Hz}, 2 \mathrm{H})$, $7.31-7.28(\mathrm{~m}, 4 \mathrm{H}), 7.25-7.20(\mathrm{~m}, 3 \mathrm{H}), 6.37(\mathrm{br}, 1 \mathrm{H}), 5.39$ (br, $1 \mathrm{H}), 4.48-4.33(\mathrm{~m}, 3 \mathrm{H}), 4.19-4.17(\mathrm{t}, J=7.2 \mathrm{~Hz}, 1 \mathrm{H}), 4.04-$ $3.91(\mathrm{~m}, 2 \mathrm{H}), 3.72(\mathrm{~s}, 3 \mathrm{H}), 3.10(\mathrm{~s}, 2 \mathrm{H}) ;{ }^{13} \mathrm{C} \mathrm{NMR}(150 \mathrm{MHz}$, $\left.\mathrm{CDCl}_{3}\right) \delta 171.3,170.0,156.2,143.9,141.5,136.5,129.5,128.9$, 127.9, 127.3, 127.2, 125.2, 120.2, 67.3, 56.2, 52.6, 47.3, 41.4, 38.6; FT-IR $\left(\mathrm{KBr}, \mathrm{cm}^{-1}\right): 3299,2921,1749,1692,1649,1540,1439$, 1260, 1032, 739; LRMS (ESI) $m / z:[\mathrm{M}+\mathrm{H}]^{+}$calcd for $\mathrm{C}_{27} \mathrm{H}_{27} \mathrm{~N}_{2} \mathrm{O}_{5} 459.1920$, found 459.1874 .

(S)-Methyl-2-((S)-2-((tert-butoxycarbonyl)amino)-3phenylpropanamido)-2-phenylacetate (30). White solid (288 mg, 70\%); $R_{\mathrm{f}}=0.50$ (EtOAc/hexane) 4:6; mp 126-128 ${ }^{\circ} \mathrm{C}$; ${ }^{1} \mathrm{H} \mathrm{NMR}\left(600 \mathrm{MHz}, \mathrm{CDCl}_{3}\right) \delta 7.32(\mathrm{~s}, 3 \mathrm{H}), 7.28-7.11(\mathrm{~m}, 7 \mathrm{H})$, $6.93(\mathrm{br}, 1 \mathrm{H}), 5.48(\mathrm{br}, 1 \mathrm{H}), 4.98(\mathrm{br}, 1 \mathrm{H}), 4.42(\mathrm{br}, 1 \mathrm{H}), 3.69$ (s, $3 \mathrm{H}), 3.12-3.00(\mathrm{~m}, 2 \mathrm{H}), 1.40(\mathrm{~s}, 9 \mathrm{H}) ;{ }^{13} \mathrm{C}$ NMR (150 MHz, $\left.\mathrm{CDCl}_{3}\right) \delta 171.1,170.9,155.6,136.6,136.4,129.6,129.5,129.1$, 129.0, 128.9, 128.7, 127.4, 127.1, 80.5, 56.7, 55.7, 53.0, 38.3, 28.4; FT-IR (KBr, cm $\left.{ }^{-1}\right): 2979,1750,1648,1535,1269,1168,1017$, 699; HRMS (ESI) $m / z:[\mathrm{M}+\mathrm{H}]^{+}$calcd for $\mathrm{C}_{23} \mathrm{H}_{29} \mathrm{~N}_{2} \mathrm{O}_{5}$ 413.2076, found 413.2077.

(S)-Methyl-2-((S)-2-((tert-butoxycarbonyl)amino)-3phenylpropanamido)-4-methylpentanoate (3p). White solid (290 mg, 74\%); $R_{\mathrm{f}}=0.50$ (EtOAc/hexane) 4:6; mp 86$88^{\circ} \mathrm{C} ;{ }^{1} \mathrm{H}$ NMR $\left(600 \mathrm{MHz}, \mathrm{CDCl}_{3}\right) \delta 7.30-7.28(\mathrm{t}, J=7.2 \mathrm{~Hz}$, $2 \mathrm{H}), 7.25-7.20(\mathrm{~m}, 3 \mathrm{H}), 6.28(\mathrm{br}, 1 \mathrm{H}), 5.02(\mathrm{br}, 1 \mathrm{H}), 4.57-4.55$ $(\mathrm{t}, J=8.4 \mathrm{~Hz}, 1 \mathrm{H}), 4.35-4.34(\mathrm{~d}, J=6.0 \mathrm{~Hz}, 1 \mathrm{H}), 3.69(\mathrm{~s}, 3 \mathrm{H})$, 3.07-3.06 (m, 2H), 1.60-1.55 (m, 2H), 1.49-1.45 (m, 1H), $1.41(\mathrm{~s}, 9 \mathrm{H}), 0.91-0.85(\mathrm{~m}, 6 \mathrm{H}) ;{ }^{13} \mathrm{C} \mathrm{NMR}\left(150 \mathrm{MHz}, \mathrm{CDCl}_{3}\right)$ $\delta 173.1,171.3,155.6,136.7,129.5,129.4,128.7,128.6,127.0$, 80.3, 55.7, 52.4, 50.9, 41.6, 38.2, 28.4, 24.8, 22.8; FT-IR (KBr, $\left.\mathrm{cm}^{-1}\right):$ 2959, 2870, 1751, 1691, 1510, 1367, 1172, 702; HRMS (ESI) $m / z:[\mathrm{M}+\mathrm{H}]^{+}$calcd for $\mathrm{C}_{21} \mathrm{H}_{33} \mathrm{~N}_{2} \mathrm{O}_{5}$ 393.2389, found 393.2389.

(S)-Methyl-2-((S)-2-(((benzyloxy)carbonyl)amino)propanamido)-3-phenylpropanoate (3q). White solid (330 $\mathrm{mg}, 86 \%) ; R_{\mathrm{f}}=0.50$ (EtOAc/hexane) 4:6; mp 99-101 ${ }^{\circ} \mathrm{C} ;{ }^{1} \mathrm{H}$
NMR $\left(400 \mathrm{MHz}, \mathrm{CDCl}_{3}\right) \delta 7.34-7.31(\mathrm{~m}, 5 \mathrm{H}), 7.27-7.18(\mathrm{~m}$, $3 \mathrm{H}), 7.10-7.08(\mathrm{~d}, J=6.8 \mathrm{~Hz}, 2 \mathrm{H}), 6.80(\mathrm{br}, 1 \mathrm{H}), 5.56(\mathrm{br}, 1 \mathrm{H})$, 5.12-5.03 (m, 2H), 4.87-4.82 (m, 1H), $4.28(\mathrm{br}, 1 \mathrm{H}), 3.69(\mathrm{~s}$, $3 \mathrm{H}), 3.15-3.02(\mathrm{~m}, 2 \mathrm{H}), 1.32-1.31(\mathrm{~d}, J=10.2 \mathrm{~Hz}, 3 \mathrm{H}) ;{ }^{13} \mathrm{C}$ NMR $\left(100 \mathrm{MHz}, \mathrm{CDCl}_{3}\right) \delta 172.2,171.9,156.0,136.3,135.8$, 129.4, 128.6, 128.3, 128.1, 127.2, 67.1, 53.4, 52.5, 50.5, 37.9, 18.6; FT-IR $\left(\mathrm{KBr}, \mathrm{cm}^{-1}\right): 2925,1757,1691,1537,1451,1265,1072$, 734, 695; HRMS (ESI) $m / z:[\mathrm{M}+\mathrm{H}]^{+}$calcd for $\mathrm{C}_{21} \mathrm{H}_{25} \mathrm{~N}_{2} \mathrm{O}_{5}$ 385.1763 , found 385.1758 .

(S)-Methyl-2-((S)-2-(((benzyloxy)carbonyl)amino)-3phenylpropanamido)-3-methylbutanoate (3r). White solid (342 mg, 83\%); $R_{\mathrm{f}}=0.50$ (EtOAc/hexane) 4:6; mp 103-105 ${ }^{\circ} \mathrm{C} ;{ }^{1} \mathrm{H}$ NMR $\left(600 \mathrm{MHz}, \mathrm{CDCl}_{3}\right) \delta 7.36-7.18(\mathrm{~m}$, $10 \mathrm{H}), 6.33$ (br, 1H), 5.39 (br, $1 \mathrm{H}), 5.11-5.06$ (m, 2H), 4.46$4.43(\mathrm{~m}, 2 \mathrm{H}), 3.68(\mathrm{~s}, 3 \mathrm{H}), 3.08-3.04(\mathrm{~m}, 2 \mathrm{H}), 2.10-2.06(\mathrm{~m}$, $1 \mathrm{H}), 0.85-0.71(\mathrm{~m}, 6 \mathrm{H}) ;{ }^{13} \mathrm{C} \mathrm{NMR}\left(150 \mathrm{MHz}, \mathrm{CDCl}_{3}\right) \delta 171.9$, 170.9 , 156.1, 136.5, 136.3, 129.5, 129.4, 129.0, 128.9, 128.7, 128.4, 128.3, 128.2, 127.3, 127.2, 67.3, 57.5, 56.4, 52.3, 38.5, 31.4, 19.0, 17.9; FT-IR (KBr, cm $\left.{ }^{-1}\right): 2956,1741,1655,1528,1286$, 750, 699; HRMS (ESI) $m / z:[\mathrm{M}+\mathrm{H}]^{+}$calcd for $\mathrm{C}_{23} \mathrm{H}_{29} \mathrm{~N}_{2} \mathrm{O}_{5}$ 413.2076, found 413.2081.

Methyl-8-benzyl-11-isopropyl-3,6,9-trioxo-1-phenyl2-oxa-4,7,10-triazadodecan-12-oate (3s). White solid (422 $\mathrm{mg}, 90 \%) ; R_{\mathrm{f}}=0.40$ (EtOAc/hexane) 4:6; mp $101{ }^{\circ} \mathrm{C} ;{ }^{1} \mathrm{H}$ NMR $\left(600 \mathrm{MHz}, \mathrm{CDCl}_{3}\right) \delta 7.32-7.30(\mathrm{~m}, 5 \mathrm{H}), 7.21-7.13(\mathrm{~m}, 5 \mathrm{H})$, $5.87(\mathrm{br}, 1 \mathrm{H}), 5.08(\mathrm{~s}, 2 \mathrm{H}), 4.82(\mathrm{br}, 1 \mathrm{H}), 4.42-4.40(\mathrm{~m}, 1 \mathrm{H})$, $3.89-3.80(\mathrm{~m}, 1 \mathrm{H}), 3.65(\mathrm{~s}, 3 \mathrm{H}), 3.06-3.00(\mathrm{~m}, 2 \mathrm{H}), 2.07-2.04$ $(\mathrm{m}, 1 \mathrm{H}), 0.83-0.82(\mathrm{~d}, J=7.2 \mathrm{~Hz}, 3 \mathrm{H}), 0.80-0.79(\mathrm{~d}, J=6.6 \mathrm{~Hz}$, $3 \mathrm{H}) ;{ }^{13} \mathrm{C} \mathrm{NMR}\left(150 \mathrm{MHz}, \mathrm{CDCl}_{3}\right) \delta 172.0,171.2,169.5,156.8$, $136.5,136.4,129.5,128.7,128.3,128.2,127.1,67.3,57.6,54.6$, 52.2, 44.5, 38.5, 31.2, 19.0, 18.0; FT-IR $\left(\mathrm{KBr}, \mathrm{cm}^{-1}\right)$ : 3406, 1728, 1677, 1651, 1646, 763, 543; HRMS (ESI) $m / z:[\mathrm{M}+\mathrm{H}]^{+}$calcd for $\mathrm{C}_{25} \mathrm{H}_{32} \mathrm{~N}_{3} \mathrm{O}_{6} 470.2291$, found 470.2295 .

Recovered 2,4,6-Trichlorobenzoic Acid (Scheme 4). White solid; $R_{\mathrm{f}}=0.40$ (EtOAc/hexane) $4: 6 ; \mathrm{mp} 162-164{ }^{\circ} \mathrm{C} ;{ }^{1} \mathrm{H}$ $\operatorname{NMR}\left(600 \mathrm{MHz}^{\mathrm{CDCl}}{ }_{3}\right) \delta 9.98$ (br s, $\left.1 \mathrm{H}\right), 7.39(\mathrm{~s}, 2 \mathrm{H}) ;{ }^{13} \mathrm{C}$ NMR $\left(150 \mathrm{MHz}, \mathrm{CDCl}_{3}\right) \delta 169.5,136.9,132.8,131.3,128.4$; FT-IR $\left(\mathrm{KBr}, \mathrm{cm}^{-1}\right): 3449,1717,1579,1390,1281,1126,849$; LRMS (ESI) $m / z$ : $[\mathrm{M}-\mathrm{H}]^{+}$calcd for $\mathrm{C}_{6} \mathrm{H}_{3} \mathrm{Cl}_{3} \mathrm{O}_{2}$ 222.9121, found 222.9214.

Recovered (E)-Ethyl-2-cyano-2-(hydroxyimino)acetate (Scheme 4). Yellow solid; $R_{\mathrm{f}}=0.40$ (EtOAc/hexane) 4:6; mp $130-134{ }^{\circ} \mathrm{C}$; ${ }^{1} \mathrm{H}$ NMR $\left(600 \mathrm{MHz}, \mathrm{CDCl}_{3}\right) \delta 4.41-4.37(\mathrm{q}, 2 \mathrm{H})$, $1.37-1.35(\mathrm{t}, J=7.2 \mathrm{~Hz}, 3 \mathrm{H}) ;{ }^{13} \mathrm{C} \mathrm{NMR}\left(150 \mathrm{MHz}, \mathrm{CDCl}_{3}\right) \delta$ 159.0, 126.1, 107.9, 63.8, 14.0; FT-IR $\left(\mathrm{KBr}, \mathrm{cm}^{-1}\right): 1729,1433$, 1314, 1071, 849, 767; LRMS (ESI) $m / z:[\mathrm{M}-\mathrm{H}]^{+}$calcd for $\mathrm{C}_{4} \mathrm{H}_{6} \mathrm{~N}_{2} \mathrm{O}_{3}$ 141.0300, found 141.0510.

\section{ASSOCIATED CONTENT}

\section{Supporting Information}

The Supporting Information is available free of charge on the ACS Publications website at DOI: 10.1021/acsomega.8b00732.

Copies of the HPLC profiles; HPLC spectra for racemization study; and copies of characterization spectra for all of the synthesized compounds (PDF)

\section{AUTHOR INFORMATION}

Corresponding Author

*E-mail: bmandal@iitg.ernet.in. Phone: (+91)-361-258-2319.

ORCID $\odot$

Bhubaneswar Mandal: 0000-0003-3435-5443 


\section{Notes}

The authors declare no competing financial interest.

\section{ACKNOWLEDGMENTS}

The authors are grateful to the Central Instruments Facility (CIF), IITG, for NMR, and the Department of Biotechnology, Govt. of India (twinning program for the North Eastern Region, sanction no. BT/PR16164/NER/95/88/2015), for financial support. They also acknowledge the DST FIST program for the HRMS facility.

\section{REFERENCES}

(1) Humphrey, J. M.; Chamberlin, A. R. Chemical Synthesis of Natural Product Peptides: Coupling Methods for the Incorporation of Noncoded Amino Acids into Peptides. Chem. Rev. 1997, 97, 2243.

(2) Ghose, A. K.; Viswanadhan, V. N.; Wendoloski, J. J. A KnowledgeBased Approach in Designing Combinatorial or Medicinal Chemistry Libraries for Drug Discovery. 1. A Qualitative and Quantitative Characterization of Known Drug Databases. J. Comb. Chem. 1999, 1, 55-68.

(3) El-Faham, A.; Albericio, F. Peptide Coupling Reagents, More than a Letter Soup. Chem. Rev. 2011, 111, 6557-6602.

(4) Larock, R. C. Comprehensive Organic Transformations; VCH Publisher Inc.: New York, 1989; p 980.

(5) Damkaci, F.; DeShong, P. Stereoselective Synthesis of $\alpha$ - and $\beta$ Glycosylamide Derivatives from Glycopyranosyl Azides via Isoxazoline Intermediates. J. Am. Chem. Soc. 2003, 125, 4408-4409.

(6) For a recent activation, see Hardee, D. J.; Kovalchuke, L.; Lambert, T. H. Nucleophilic Acyl Substitution via Aromatic Cation Activation of Carboxylic Acids: Rapid Generation of Acid Chlorides under Mild Conditions. J. Am. Chem. Soc. 2010, 132, 5002-5003.

(7) Allen, C. L.; Chhatwal, A. R; Williams, J. M. J. Direct amide formation from unactivated carboxylic acids and amines. Chem. Commun. 2012, 48, 666-668.

(8) (a) Pattabiraman, V. R.; Jeffrey, W. B. Rethinking amide bond synthesis. Nature 2011, 480, 471-479. (b) Ishihara, K.; Ohara, S.; Yamamoto, H. Direct Condensation of Carboxylic Acids with Alcohols Catalyzed by Hafnium(IV) Salts. Science 2000, 290, 1140-1142.

(9) Shiina, I.; Kubota, M.; Oshiumi, H.; Hashizume, M. An Effective Use of Benzoic Anhydride and Its Derivatives for the Synthesis of Carboxylic Esters and Lactones: A Powerful and Convenient Mixed Anhydride Method Promoted by Basic Catalysts. J. Org. Chem. 2004, 69, $1822-1830$.

(10) Inanaga, J.; Hirata, K.; Saeki, H.; Katsuki, T.; Yamaguchi, M. A Rapid Esterification by Means of Mixed Anhydride and Its Application to Large-ring Lactonization. Bull. Chem. Soc. Jpn. 1979, 52, 1989-1993. (11) (a) Shiina, I.; Kubota, M.; Ibuka, R. A novel and efficient macrolactonization of $\omega$-hydroxycarboxylic acids using 2-methyl-6nitrobenzoic anhydride (MNBA). Tetrahedron Lett. 2002, 43, 75357539. (b) Ishihara, K.; Kubota, M.; Kurihara, H.; Yamamoto, H. Scandium Trifluoromethanesulfonate as an Extremely Active Acylation Catalyst. J. Am. Chem. Soc. 1995, 117, 4413-4414.

(12) Dhimitruka, I.; SantaLucia, J. Investigation of the Yamaguchi Esterification Mechanism. Synthesis of a Lux-S Enzyme Inhibitor Using an Improved Esterification Method. Org. Lett. 2006, 8, 47-50.

(13) Okuno, Y.; Isomura, S.; Nishibayashi, A.; Hosoi, A.; Fukuyama, K.; Ohba, M.; Takeda, K. Modified Yamaguchi reagent: convenient and efficient esterification. Synth. Commun. 2014, 44, 2854-2860.

(14) (a) Albeiicio, F.; Chinchilla, R.; Dodsworth, D. J.; Nájera, C. New Trends in Peptide Coupling Reagents. Org. Prep. Proced. Inst. 2001, 33, 203-303. (b) El-Faham, A.; Albericio, F. Novel Proton Acceptor Immonium-Type Coupling Reagents: Application in Solution and Solid-Phase Peptide Synthesis. Org. Lett. 2007, 9, 4475-4477.

(15) Subirós-Funosas, R; Prohens, R.; Barbas, R.; El-Faham, A.; Albericio, F. Oxyma: an efficient additive for peptide synthesis to replace the benzotriazole-based HOBt and HOAt with a lower risk of explosion. Chem. - Eur. J. 2009, 15, 9394-9403.
(16) (a) Mitachi, K.; Kurosu, Y. E.; Hazlett, B. T.; Kurosu, M. Oxymabased phosphates for racemization-free peptide segment couplings. J. Pept. Sci. 2016, 22, 186-191. (b) Subirós-Funosas, R.; Khattab, S. N.; Nieto-Rodriguez, L.; El-Faham, A.; Albericio, F. Low-epimerization Peptide Bond Formation with Oxyma Pure: Preparation of Z-L-PhgVal-OMe. Aldrichim. Acta 2013, 46, 21-40.

(17) (a) Dev, D.; Palakurthy, N. B.; Thalluri, K.; Chandra, J.; Mandal, B. Ethyl 2-Cyano-2-(2-nitrobenzenesulfonyloxyimino)acetate (o-Nosy1OXY): A Recyclable Coupling Reagent for Racemization-Free Synthesis of Peptide, Amide, Hydroxamate, and Ester. J. Org. Chem. 2014, 79, 5420-5431. (b) Thalluri, K.; Manne, S. R.; Dev, D.; Mandal, B. Ethyl 2-Cyano-2-(4-nitrophenylsulfonyloxyimino)acetate-Mediated Lossen Rearrangement: Single-Pot Racemization-Free Synthesis of Hydroxamic Acids and Ureas from Carboxylic Acids. J. Org. Chem. 2014, 79, 3765-3775. (c) Dev, D.; Chandra, J.; Palakurthy, N. B.; Thalluri, K.; Kalita, T.; Mandal, B. Benzoxazole and Benzothiazole Synthesis from Carboxylic Acids in Solution and on Resin by Using Ethyl 2-Cyano-2-(2nitrobenzenesulfonyloxyimino)acetate and para-Toluenesulfonic Acid. Asian J. Org. Chem. 2016, 5, 663-675. (d) Dev, D.; Palakurthy, N. B.; Kumar, N.; Mandal, B. An unexpected involvement of ethyl-2-cyano-2(hydroxyimino) acetate cleaved product in the promotion of the synthesis of nitriles from aldoximes: a mechanistic perception. Tetrahedron Lett. 2013, 54, 4397-4400. (e) Manne, S. R.; Thalluri, K.; Giri, R. S.; Chandra, J.; Mandal, B. Ethyl 2-(tert-Butoxycarbonyloxyimino)-2-cyanoacetate (Boc-Oxyma): An Efficient Reagent for the Racemization Free Synthesis of Ureas, Carbamates and Thiocarbamates via Lossen Rearrangement. Adv. Synth. Catal. 2017, 359, 168-176. (f) Manne, S. R.; Thalluri, K.; Giri, R. S.; Paul, A.; Mandal, B. Racemization free longer $\mathrm{N}$-terminal peptide hydroxamate synthesis on solid support using ethyl 2-(tert-butoxycarbonyloxyimino)-2-cyanoacetate. Tetrahedron Lett. 2015, 56, 6108-6111. (g) Thalluri, K.; Nadimpally, K. C.; Chakravarty, M. P.; Paul, A.; Mandal, B. Ethyl 2(tert-Butoxycarbonyloxyimino)-2-cyanoacetate (Boc-Oxyma) as Coupling Reagent for Racemization-Free Esterification, Thioesterification, Amidation and Peptide Synthesis. Adv. Synth. Catal. 2013, 355, 448462.

(18) Neises, B.; Steglich, W. Simple Method for the Esterification of Carboxylic Acids. Angew. Chem., Int. Ed. 1978, 17, 522-524.

(19) El-Faham, A.; Albericio, F. Morpholine-Based Immonium and Halogenoamidinium Salts as Coupling Reagents in Peptide Synthesis. J. Org. Chem. 2008, 73, 2731-2737.

(20) Crescenzi, O.; Tomaselli, S.; Guerrini, R.; Salvadori, S.; D’Ursi, A. M.; Temussi, P. A.; Picone, D. Solution structure of the Alzheimer amyloid $\beta$-peptide (1-42) in an apolar microenvironment. Eur. J. Biochem. 2002, 269, 5642-5648.

(21) Conrad, R. M.; Grubbs, R. H. Tunable, Temperature-Responsive Polynorbornenes with Side Chains Based on an Elastin Peptide Sequence. Angew. Chem., Int. Ed. 2009, 48, 8328-8330.

(22) Tian, J.; Gao, W. C.; Zhou, D. M.; Zhang, C. Recyclable Hypervalent Iodine(III) Reagent Iodosodilactone as an Efficient Coupling Reagent for Direct Esterification, Amidation, and Peptide Coupling. Org. Lett. 2012, 14, 3020-3023.

(23) Gedye, R.; Smith, F.; Westaway, K.; Ali, H.; Baldisera, L.; Laberge, L.; Rousell, J. The use of microwave ovens for rapid organic synthesis. Tetrahedron Lett. 1986, 27, 279-282. 